\title{
TOXICIDADE DE AGROTÓXICOS UTILIZADOS NO CONTROLE DE Bemisia tabaci BIÓTIPO B, SOBRE FUNGOS ENTOMOPATOGÊNICOS
}

\author{
MELISSA FAION
}

\begin{abstract}
Dissertação apresentada à Escola Superior de Agricultura "Luiz de Queiroz", Universidade de São Paulo, para obtenção do título de Mestre em Ciências. Área de Concentração: Entomologia.
\end{abstract}

P I R A C I C A B A

Estado de São Paulo - Brasil

Novembro - 2004 


\title{
TOXICIDADE DE AGROTÓXICOS UTILIZADOS NO CONTROLE DE Bemisia tabaci BIÓTIPO B, SOBRE FUNGOS ENTOMOPATOGÊNICOS
}

\author{
MELISSA FAION \\ Bióloga
}

Orientador: Prof. Dr. SÉRGIO BATISTA ALVES

Dissertação apresentada à Escola Superior de Agricultura "Luiz de Queiroz”, Universidade de São Paulo, para obtenção do título de Mestre em Ciências. Área de Concentração: Entomologia.

P I R A C I C A B A

Estado de São Paulo - Brasil

Novembro - 2004 


\section{Dados Internacionais de Catalogação na Publicação (CIP) DIVISÃO DE BIBLIOTECA E DOCUMENTAÇÃO - ESALQ/USP}

Faion, Melissa

Toxicidade de agrotóxicos utilizados no controle de Bemisia tabaci biótipo B, sobre fungos entomopatogênicos / Melissa Faion. - - Piracicaba, 2004.

72 p. : il.

Dissertação (mestrado) - - Escola Superior de Agricultura Luiz de Queiroz, 2004.

Bibliografia.

1. Controle biológico 2. Controle fitossanitário 3. Fungo entomopatogênico 4. Moscabranca 5. Pesticida 6. Praga de planta 7. Produto fitossanitário 8. Tomate 9. Toxicologia I. Título

CDD 632.96 
Aos meus pais, ODAIR e CLAUDETE As minhas irmãs, MAYRA e MILENE A minha sobrinha TAINÁ Ao MURILO 


\section{AGRADECIMENTOS}

Ao Prof. Sérgio Batista Alves pela orientação e oportunidade para a realização deste trabalho.

Aos professores do Departamento de Entomologia (ESALQ/USP) pelos ensinamentos e colaboração.

À bióloga Solange Aparecida Vieira pela amizade e auxílio na condução dos experimentos.

A todos os colegas do laboratório de Patologia e Controle Microbiano de Insetos, Rogério B. Lopes, Luciana S. Rossi, Marco A. Tamai, Marcel R. Tanzini, Daniella Macedo, Ricardo A. Polanczk, Marcelo O. Garcia, Juan H. G. Molina, Michelle L. Rodrigues, Giuliano Pauli, Daniela Marinheiro, Gabriel M. Moura e Thiago Mastrangelo pela amizade e companheirismo.

À todas as pessoas da minha família, minhas avós, tios (as), primos (as) que sempre estiveram presentes em todas as etapas importantes da minha vida.

Às minhas amigas de “república” Melissa D. Tomazini, Márcia M. A. de Souza e agregada Tatiele A. B. Fenilli pela convivência e amizade.

À Dra. Marinéia de Lara Haddad pelo auxílio nas análises estatísticas. 
Ao Prof. Dr. Ítalo Delalibera Júnior pelo auxílio na elaboração e correção do summary.

À bibliotecária Eliana Maria Garcia pela atenção e correção da estrutura deste trabalho.

A todos que sempre me incentivaram e me apoiaram.

Ao CNPq e a CAPES, pela bolsa de estudo que possibilitou a execução desse trabalho. 


\section{SUMÁRIO}

\begin{tabular}{|c|c|}
\hline LISTA DE FIGURAS.. & $\begin{array}{c}\text { Página } \\
\text { viii }\end{array}$ \\
\hline LISTA DE TABELAS. & $\mathrm{X}$ \\
\hline RESUMO... & xii \\
\hline SUMMARY ............... & xiii \\
\hline 1 INTRODUÇÃO & 1 \\
\hline 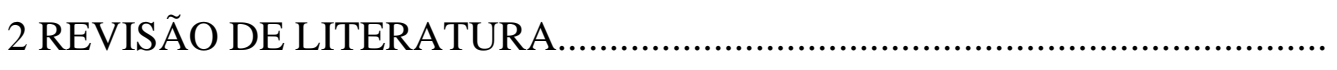 & 3 \\
\hline 2.1 Bioecologia e danos causados por Bemisia tabaci........................................... & 3 \\
\hline 2.2 Controle químico de B. tabaci..... & 5 \\
\hline 2.3 Controle biológico de $B$. tabaci.................... & 9 \\
\hline 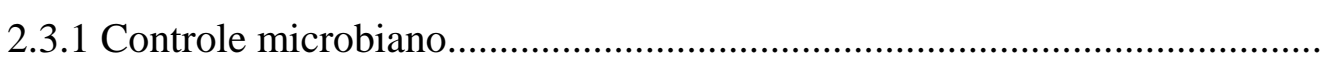 & 11 \\
\hline 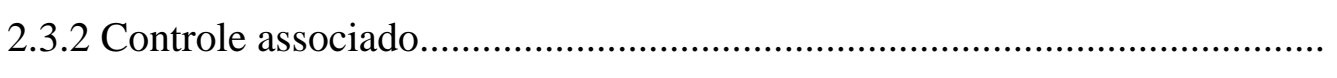 & 17 \\
\hline 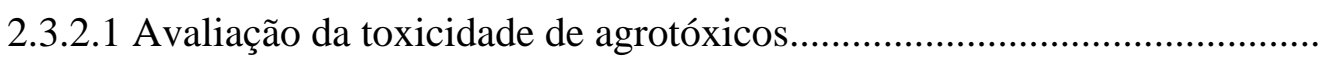 & 19 \\
\hline 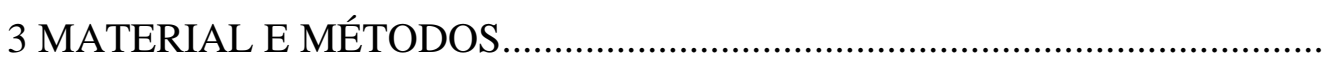 & 23 \\
\hline 3.1 Criação e manutenção de B. tabaci em casa-de-vegetação................................ & 23 \\
\hline 3.2 Toxicidade de produtos fitossanitários a B. bassiana e $M$. anisopliae............ & 23 \\
\hline 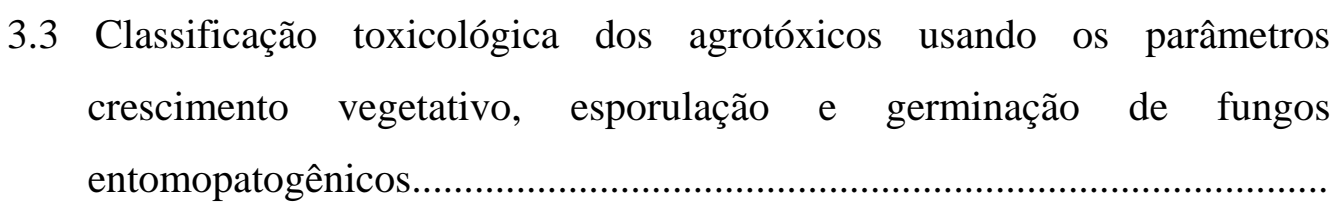 & 26 \\
\hline 3.4 Efeito de subdoses de spiromesifen sobre ninfas de $B$. tabaci........................ & 28 \\
\hline 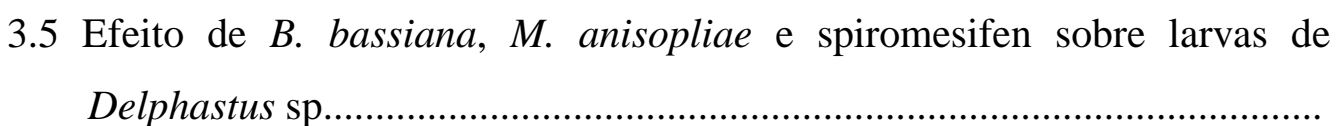 & 29 \\
\hline
\end{tabular}

3.6 Efeito da associação de spiromesifen e fungos entomopatogênicos sobre ninfas de $B$. tabaci em tomateiros sob condição de cultivo em 
estufa...

30

4 RESULTADOS E DISCUSSÃO.............................................................. 33

4.1 Criação e manutenção de B. tabaci em casa-de-vegetação............................. 33

4.2 Toxicidade de produtos fitossanitários a B. bassiana e M. anisopliae........... 34

4.3 Classificação toxicológica dos agrotóxicos usando os parâmetros crescimento vegetativo, esporulação e germinação de fungos entomopatogênicos................................................................................. 39

4.4 Efeito de subdoses de spiromesifen sobre ninfas de B. tabaci..................... 49

4.5 Efeito de $B$. bassiana e $M$. anisopliae e spiromesifen sobre larvas de

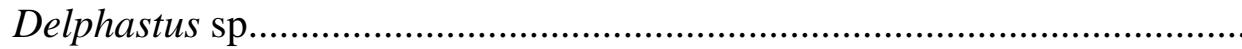

4.6 Efeito da associação de spiromesifen e fungos entomopatogênicos sobre ninfas de $B$. tabaci em tomateiros sob condição de cultivo protegido..

5 CONCLUSÕES. 61

REFERÊNCIAS BIBLIOGRÁFICAS 


\section{LISTA DE FIGURAS}

Página

1 Análise de Agrupamento (Cluster) do crescimento vegetativo (CV), esporulação (ESP) e germinação (GER) de Beauveria bassiana (ESALQ 447)

2 Análise de Agrupamento (Cluster) do crescimento vegetativo (CV), esporulação (ESP) e germinação (GER) de Metarhizium anisopliae (ESALQ E9).

3 Porcentagem de mortalidade diária de ninfas de $3^{\circ}$ ínstar de Bemisia tabaci tratadas spiromesifen.

4 Número de adultos de Bemisia tabaci antes do início das pulverizações (0 dia) e após um dia da realização da primeira pulverização..

5 Número de adultos de Bemisia tabaci antes do início das pulverizações (0 dia) e após sete dias da realização da primeira pulverização, ou seja, após 3 pulverizações.

6 Número de adultos de Bemisia tabaci antes do início das pulverizações (0 dia) e após quinze dias da realização da primeira pulverização, ou seja, após 6 pulverizações.

7 Número de ninfas vivas e mortas de Bemisia tabaci, após 11 pulverizações ( $\left.\cong 26^{\circ} \mathrm{C} ; 75 \% \mathrm{UR}\right)$

8 Número de ninfas vivas e mortas de Bemisia tabaci, após 14 pulverizações

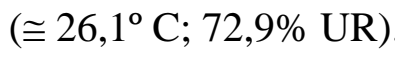


9 Número de ninfas vivas e mortas de Bemisia tabaci, após 16 pulverizações

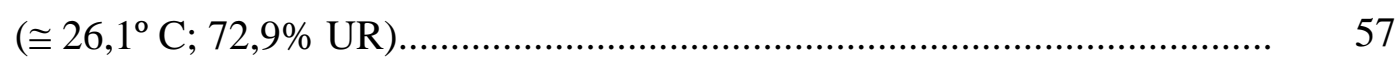

10 Número de ninfas vivas e mortas de Bemisia tabaci, após 18 pulverizações

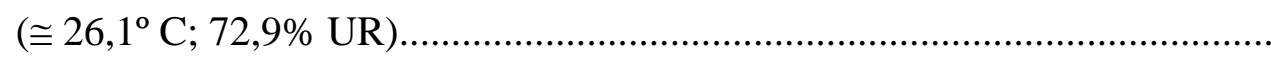




\section{LISTA DE TABELAS}

Página

1 Descrição de inseticidas utilizados nos testes de toxicidade (Andrei, 1999)

2 Valores de T para classificação do efeito de produtos químicos sobre fungos

(Alves et al., 1998a)

3 Diâmetro da colônia e número de conídios, após 7 dias da inoculação e porcentagem do fungo Beauveria bassiana (ESALQ 447) na presença de diferentes agrotóxicos (meio de cultura BDA, $26 \pm 0,5^{\circ} \mathrm{C}, 70 \pm 10 \%$ UR e 12 $\mathrm{h}$ de fotofase)

4. Diâmetro da colônia e número de conídios, após 7 dias da inoculação e porcentagem do fungo Metarhizium anisopliae (ESALQ E9) na presença de diferentes agrotóxicos (meio de cultura BDA, $26 \pm 0,5^{\circ} \mathrm{C}, 70 \pm 10 \%$ UR e $12 \mathrm{~h}$ de fotofase).

5 Valores de T e classificação de compatibilidade dos produtos fitossanitários, em relação ao efeito fungitóxico em Beauveria bassiana (ESALQ 447) e Metarhizium anisopliae (ESALQ E9).

6 Valores de crescimento vegetativo (CV), esporulação (ESP) e germinação (GER) corrigidos pela testemunha, valor de $\mathrm{T}$ e respectiva classificação

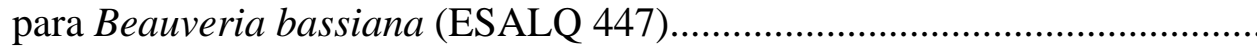

7 Valores de crescimento vegetativo (CV), esporulação (ESP) e germinação (GER) corrigidos pela testemunha, valor de $\mathrm{T}$ e respectiva classificação para Metarhizium anisopliae (ESALQ E9)

8 Porcentagem de mortalidade de ninfas de $3^{\circ}$ ínstar de Bemisia tabaci 
tratadas com subdoses de spiromesifen..................................................... 


\title{
TOXICIDADE DE AGROTÓXICOS UTILIZADOS NO CONTROLE DE Bemisia tabaci BIÓTIPO B, SOBRE FUNGOS ENTOMOPATOGÊNICOS
}

\author{
Autora: MELISSA FAION \\ Orientador: Prof. Dr. SÉRGIO BATISTA ALVES
}

\section{RESUMO}

Determinou-se a toxicidade de dezoito formulações de agrotóxicos utilizados no controle de Bemisia tabaci (Hemiptera: Aleyrodidae) biótipo B na cultura do tomate, sobre os fungos entomopatogênicos Beauveria bassiana (ESALQ 447) Metarhizium anisopliae (ESALQ E9). Para isso, avaliou-se o crescimento vegetativo, esporulação e germinação dos patógenos submetidos a ação das formulações, sugerindo-se uma alteração na expressão matemática para classificação da toxicidade de agrotóxicos. Subdoses (de 5,0 a 1,25 mL/ L) do produto Oberon 240 SC (spiromesifen) foram testadas sobre ninfas de $3^{\circ}$ ínstar de B. tabaci. As mortalidades obtidas nos tratamentos variaram de 35,3 a 79,9\%. A ação de B. bassiana e $M$. anisopliae e sua associação com o Oberon 240 SC foi testada sobre larvas do predador de B. tabaci, Delphastus sp. (Coleptera: Coccinellidae), não sendo observado efeito dos produtos sobre os insetos pulverizados. Os melhores tratamentos para o controle de B. tabaci em tomateiros foram obtidos pelo tratamento com 2,5 mL/ L de Oberon 240 SC e sua associação com 20 g/ L de B. bassiana. 


\title{
TOXICITY OF PESTICIDES USED AGAINST Bemisia tabaci BIOTIPE B, ON ENTOMOATHOGENIC FUNGI
}

\author{
Author: MELISSA FAION \\ Adviser: Prof. Dr. SÉRGIO BATISTA ALVES
}

\section{SUMMARY}

The toxicity of eighteen insecticides used to control Bemisia tabaci (Hemiptera: Aleyrodidae) biotipe $\mathrm{B}$ in tomato, was evaluated on the entomopathogenic fungi Beauveria bassiana (ESALQ 447) and Metarhizium anisopliae (ESALQ E9). It was evaluated the effect of pesticides on the pathogen growth, sporulation and germination. Bases on our findings we suggested a new mathematical expression for classification of the toxicity of pesticides. Sublethal doses (5.0 to $1.25 \mathrm{~mL} / \mathrm{L}$ ) of Oberon $240 \mathrm{SC}$ were tested on the third nymph instar of B. tabaci, and mortalities varied from 35.3 to $79.9 \%$. Use of Oberon 240 SC combines with B. bassiana and M. anisopliae did not effect Delphastus sp (Coleoptera: Coccinellidae), a predator of $B$. tabaci larvae. The best treatments for control of B. tabaci in tomato were obtained by spray of $2.5 \mathrm{~mL} / \mathrm{L}$ of Oberon 240 SC with $20 \mathrm{~g} / \mathrm{L}$ of B. bassiana. 


\section{INTRODUÇÃO}

Bemisia tabaci (Gennadius, 1889) (Hemiptera: Aleyrodidae) biótipo B, é um inseto encontrado nas principais regiões agrícolas do mundo, adaptado especialmente às regiões de clima quente e umidade elevada. Os seus danos podem ser ocasionados tanto por adultos como por ninfas. Esses ocorrem devido a sucção da seiva e indiretamente, pela disseminação de vírus fitopatogênicos e favorecimento da "fumagina" que desenvolve nas substâncias açucaradas ("honeydew"), produto de excreção do inseto.

Atualmente este inseto tem causado danos altamente significativos devido à sua característica polífaga, alta capacidade reprodutiva, e principalmente, pelo desenvolvimento de resistência a alguns inseticidas, o que dificulta o controle em campo.

Diversas medidas têm sido utilizadas para o controle da mosca-branca, sendo a mais freqüente o controle químico. Apesar de ser eficaz, o controle biológico tem sido pouco usado. Essa praga possui diversos inimigos naturais que podem ser efetivos para o seu controle, destacando-se parasitóides, predadores e patógenos. No controle microbiano, os fungos entomopatogênicos têm sido os mais utilizados, representando uma importante tática dentro do manejo integrado desta praga.

Muitos fungos entomopatogênicos são citados na literatura como eficientes no controle de B. tabaci em condições de cultivo protegido e em campo, ocorrendo naturalmente ou sendo introduzidos de maneira inundativa. Dentre esses, destacam-se Paecilomyces fumosoroseus, Verticillium spp., Beauveria bassiana e Metarhizium anisopliae. A disponibilidade no mercado, além da compatibilidade com outros métodos de controle são características que favorecem sua utilização prática. 
Este trabalho teve como objetivos avaliar a toxicidade de 18 produtos fitossanitários comercialmente utilizados no controle de $B$. tabaci sobre os fungos entomopatogênicos $B$. bassiana e $M$. anisopliae, desenvolver um modelo para classificação da toxicidade desses produtos e medir o efeito de subdosagem do produto fitossanitário Oberon 240 SC (spiromesifen) associado a B. bassiana e M. anisopliae em condições de semi-campo. 


\section{REVISÃO DE LITERATURA}

\subsection{Bioecologia e danos causados por Bemisia tabaci}

Bemisia tabaci é um inseto que apresenta o hábito de sugar a seiva dos feixes vasculares das plantas (Byrne \& Bellows, 1991). Possue um aparelho bucal do tipo sugador labial tetraqueta, com canal de sucção e de saliva formados pela justaposição dos estiletes maxilares.

Este inseto apresenta metamorfose incompleta e sua reprodução ocorre de forma sexuada por oviparidade ou partenogênese arrenótoca. O ciclo de vida da moscabranca constitui-se da fase de ovo, um ínstar ninfal móvel que se alimenta, dois ínstares ninfais imóveis, e um quarto ínstar ninfal incorretamente denominado de "pupa". Na fase adulta os dois sexos apresentam dois pares de asas membranosas recobertas por uma secreção pulverulenta branca, e por este motivo recebe o nome de mosca-branca (Byrne \& Bellows, 1991). Tanto os adultos quanto os estágios imaturos de B. tabaci têm o hábito de colonizar a face inferior das folhas de muitas plantas hospedeiras (Simmons, 1994).

As moscas-brancas são multivoltinas, com duas a seis gerações por ano. Muitas espécies ocorrem em regiões tropicais e subtropicais, podendo-se desenvolver e reproduzir continuamente devido às condições propícias de temperatura (Byrne \& Bellows, 1991). O período de desenvolvimento de moscas-brancas multivoltinas geralmente modifica-se com a estação, mas muitas espécies relatadas desenvolvem-se de ovo a adulto em cerca de 25 a 50 dias em condições de campo.

Segundo Byrne \& Bellows (1991) fatores abióticos como temperatura e fotoperíodo podem afetar o desenvolvimento da mosca-branca. Sob temperatura 
constante de $29,5 \pm 0,6^{\circ} \mathrm{C}$ e fotoperíodo de $14: 10$, 90\% de adultos de $B$. tabaci emergem entre 25 e 40 dias. Tem-se observado que períodos secos e quentes favorecem o desenvolvimento e a dispersão da praga, sendo por isso observados maiores picos populacionais na estação seca. Durante a noite observou-se pouca emergência de adultos, sendo que o pico de emergência se atrasa quando ocorre flutuação da temperatura, não ocorrendo emergência em temperaturas abaixo de $17^{\circ} \mathrm{C}$.

São hospedeiros preferenciais de Bemisia tabaci biótipo B, descrita inicialmente como Bemisia argentifolii (Bellows et al., 1994): algodão, brássicas (brócolis, couve-flor, repolho), cucurbitáceas (abobrinha, melão, chuchu, melancia, pepino), leguminosas (feijão, feijão-de-vagem, soja), solanáceas (berinjela, fumo, pimenta, tomate, pimentão), uva e algumas ornamentais como o bico-de-papagaio (Euphorbia pulcherrima). Também tem sido relatada em plantas daninhas como o picão, joá-de-capote, amendoim-bravo e datura. No Brasil a primeira constatação da presença desse inseto foi feita no Estado de São Paulo no início da década de 90 (Lourenção \& Nagai, 1994), quando surtos populacionais foram observados em plantas ornamentais (poinsétia e crisântemo), em lavouras de abóbora (Cucurbita moschata) e de tomate (Lycopersicon esculentum) (Silva et al., 2004; Herbário, 2004).

Esta praga provoca perdas devido ao dano direto, em virtude da sucção de seiva durante a alimentação, além da introdução de substâncias tóxicas às plantas (Byrne \& Bellows, 1991), podendo causar o prateamento das folhas em abóbora, crescimento irregular dos frutos do tomateiro, embranquecimento do caule em Brassica spp., clareamento das veias em poinsétia e da raiz em cenoura, entre outros sintomas. Também causa danos indiretos pela transmissão de vírus e excreção de "honeydew”, substância que propicia o desenvolvimento da fumagina e prejudica os processos fisiológicos das folhas, podendo ainda, afetar a qualidade da produção quando incidir sobre os frutos (Valle et al., 2002).

Em casos de altas densidades populacionais, podem ocorrer perdas de até 50\% na produção de tomate. Infestações muito intensas ocasionam murcha, queda de folhas e perda de frutos. Em tomate para processamento industrial, ocorre o amadurecimento irregular dos frutos, provavelmente causado por uma toxina injetada pelo inseto. Isso 
dificulta o reconhecimento do ponto de colheita dos frutos e reduz a produção e a qualidade da pasta. Internamente os frutos ficam esbranquiçados, com aspecto esponjoso ou "isoporizados". (Silva et al., 2004)

B. tabaci é capaz de transmitir para as plantas, vírus de sete grupos distintos, como: geminivirus, closterovirus, carlavirus, potyvirus, nepovirus, luterovirus e um vírus de partícula livre de DNA. Os mais importantes são os geminivirus (Família Geminiviridae: Gênero Begomovirus) e os closterovirus (Família Closteroviridae: Gênero Crinivirus). Estes vírus atingem diversas culturas, no entanto, as geminiviroses que infectam tomate, feijão e mandioca são citadas como as mais distribuídas e importantes em todo o mundo (Oliveira et al., 2001).

Segundo pesquisas do Instituto Biológico esta praga é responsável pela transmissão de dois tipos de geminivírus para plantas de tomate no Brasil: o Tomato Mosaic Rogose Virus (TMRV) e o Tomato Yellow Vein Streak Virus (TYVSV). Sintomas generalizados de geminivirus em plantas de tomate já foram observados nos Estados de Minas Gerais, São Paulo, Goiás, Espírito Santo, Rio de Janeiro, Distrito Federal, Ceará, Bahia e Pernambuco (Submédio São Francisco). Em geral, os sintomas se manifestam como clorose das nervuras a partir da base da folha, seguido de mosaico amarelo, rugosidade e até mesmo enrolamento das folhas. Quando a infecção é precoce, as perdas são totais e o controle muito difícil devido à alta população de mosca-branca presente no campo. A transmissão do vírus pelo inseto é do tipo persistente ou circulativa, isto é, uma vez adquirido o vírus a mosca-branca passa a transmiti-lo por toda a sua vida. Estes ataques podem causar perdas de 40 a 70\% na cultura do tomateiro.

Atualmente, a importância deste inseto está aumentando em cultivos comerciais, especialmente em condições de cultivo protegido, sendo citada como uma das pragas-chave nestes ambientes (Oliveira, 1995; Tamai et al., 1999).

\subsection{Controle químico de B. tabaci}

Em muitos sistemas agrícolas o uso de agrotóxicos é uma estratégia primária empregada no controle de B. tabaci. Isto foi, principalmente, evidenciado nos EUA 
durante a década passada, onde B. tabaci demonstrou um potencial para causar danos de milhões de dólares em diversas culturas (Palumbo et al., 2001). Segundo este autor, a longo prazo, a sustentação do manejo de B. tabaci com inseticidas tem-se tornado difícil, tanto em campo como em cultivo protegido. Em muitos cultivos, repetidas aplicações de inseticidas têm sido necessárias, e freqüentemente resultam no uso excessivo destes agrotóxicos.

Os agrotóxicos que têm sido mais utilizados para o controle da mosca-branca são do grupo dos organoclorados, organofosforados, carbamatos e piretróides (Arenas, 1998). Atualmente, contudo, a recomendação de piretróides tem sido limitada ao uso em rotação com outros produtos como os reguladores de crescimento (IGRs). Dentre eles destacando-se o buprofezin e o pyriproxyfen (Palumbo et al., 2001; Liu, 2004).

Para o desenvolvimento de estratégias de manejo de $B$. tabaci, um dos pontos fundamentais é a disponibilidade de produtos eficientes e seletivos a inimigos naturais. Além disso, outras estratégias podem ser utilizadas, como a redução na taxa de aplicação, uso de produtos menos persistentes, mudanças temporais e espaciais dos métodos de aplicação e na formulação. O uso, de formulações sistêmicas como o imidacloprid, entre outros inseticidas do gênero (Naranjo, 2001), visa alcançar seletividade evitando contaminação da superfície de planta.

Segundo Palumbo et al. (2001) o primeiro inseticida nicotinóide registrado para uso contra B. tabaci foi o imidacloprid. Este mostrou um período residual longo e eficiente contra B. tabaci em muitas culturas, quando utilizado no tratamento de semente, no solo e aplicado sobre as folhas. Embora esta formulação tenha sido utilizada para o controle de insetos em vários países do mundo desde 1991, o tratamento do solo com aplicações de imidacloprid, foi primeiramente utilizado nos últimos anos para o controle de B. tabaci em diversas culturas anuais, melão e em casas-de-vegetação.

Em plantas tratadas com imidacloprid, os compostos e seus metabólitos são inicialmente tóxicos aos adultos durante a alimentação, mas também podem repelir e impedir a alimentação. Conseqüentemente, o estabelecimento de formas imaturas de moscas-brancas nas plantas sofre uma grande redução devido a diminuição da oviposição. As ninfas que emergem, geralmente morrem dentro de uma semana, depois 
de se alimentarem das plantas tratadas. O controle residual de populações de $B$. tabaci pode variar de 1 a 10 semanas, dependendo da formulação, profundidade de aplicação, tipo de solo, método de aplicação e sistema de cultivo (Palumbo et al., 2001).

No entanto, em algumas culturas, o imidacloprid tem se mostrado capaz de causar fitotoxicidade em ramos de plantas jovens, dependendo da taxa e tempo de aplicação (Stansly et al., 1998). O imidacloprid também foi relatado causando repelência a pássaros e mamíferos. Em testes realizados por Marquini et al. (2003) com imidacloprid na cultura do feijão, nenhum efeito significativo foi observado sobre $B$. tabaci.

Recentemente, vários inseticidas neonicotenóides têm surgido, além do imidacloprid, incluindo o thiamethoxam, thiacloprid e acetamiprid, para o controle de moscas-brancas e afídeos em vegetais (Liu, 2004). Contudo, em testes realizados por Scarpellini et al. (2002) na cultura do feijoeiro, nenhum dos tratamentos utilizados, com imidacloprid, thiamethoxam e diafenthiuron, apresentaram eficiência satisfatória no controle de adultos de $B$. tabaci biótipo B, devido a altas infestações em culturas vizinhas.

A necessidade de uma grande diversidade de inseticidas para o controle de $B$. tabaci foi encontrada com o desenvolvimento dos inseticidas reguladores de crescimento (IGRs). O buprofezin foi o primeiro IGR seletivo introduzido para o controle de $B$. tabaci em algodão. Ele atua inibindo a síntese de quitina, agindo especificamente no desenvolvimento das formas imaturas resultando na mortalidade de ninfas durante a ecdise. Embora o buprofezin não tenha efeito direto sobre a longevidade ou oviposição de adultos de $B$. tabaci, foi sugerido que o composto possa reduzir a fecundidade e número de ovos das fêmeas expostas a folhas tratadas (Beevi \& Balasubramanian, 1991; Palumbo et al., 2001). Contudo, o buprofezin não tem atividade sistêmica no solo, além de possuir pouca ação translaminar em folhas de algodão.

Em estudos desenvolvidos por Valle et al. (2002), foram avaliadas as eficiências de pyriproxyfen, análogo do hormônio juvenil, com atuação reconhecida sobre cochonilhas e moscas-brancas e do buprofezin. Foi constatada a eficiência do pyriproxyfen sobre ninfas de $1^{\circ}$ ínstar, na dosagem de $75 \mathrm{mg} \mathrm{L}^{-1}$, reduzindo em $85 \%$ a 
emergência de adultos de B. tabaci devido principalmente a sua ação translaminar. O buprofezin, não teve ação considerável sobre as ninfas, atingindo valores de apenas $34 \%$.

Segundo Wiesbrook (2003) um novo inseticida/acaricida vem sendo desenvolvido para o controle de ácaros (Tetranychus spp.) e moscas-brancas (Bemisia spp. e Trialeurodes spp.) e outros artrópodes em algodão, vegetais, morango, citros, ornamentais e milho. Este produto pertence a uma nova classe de inseticidas nãosistêmico, que possui como ingrediente ativo o spiromesifen, um tipo de regulador de crescimento na inibição da biosíntese de lipídeo do inseto (Nauen et al., 2002 citado por Liu, 2004). Tem atuação, principalmente, sobre as ninfas e o estágio "pupal" em moscasbrancas.

Bons resultados foram obtidos por Schuster et al. (2003) em testes realizados com o produto comercial Oberon 240 SC (spiromesifen) em plantas de tomate nos anos de 2002 e 2003. Com apenas uma aplicação deste produto, obteve-se diminuição do número de ninfas de B. tabaci, abaixo do limiar de 5 ninfas para cada 10 folhas por até 4 semanas. Em testes realizados para a comparação da eficiência de produtos, como o Baythroid 2 (cyfluthrin) e Thiodan (endosulfan) para o controle de B. tabaci, o Oberon 240 SC precisou de menor número de aplicações para obter o mesmo nível de controle que os outros dois testados.

Segundo Liu (2004), spiromesifen foi altamente tóxico a ninfas de B. tabaci (aproximadamente $100 \%$ de mortalidade), em testes de laboratório com melão (cantaloupe, var. "Primo”) e couve (var. “Georgia LS”), especialmente para ninfas jovens (primeiro e segundo ínstar). O efeito não-tóxico do produto foi observado sobre os ovos, no entanto, sobre ninfas recém-eclodidas de ovos tratados com spiromesifen, a mortalidade ocorreu rapidamente, após se tornarem sésseis sobre a superfície das folhas tratadas. Para ninfas mais velhas (terceiro e quarto ínstar) e para adultos, o spiromesifen causou baixa a moderada mortalidade.

Alguns produtos quando aplicados com pulverizações foliares como o buprofezin e pyriproxyfen têm prevenido a deposição de "honeydew" e contaminação com fumagina em algodão e melão evitando também, desordens fisiológicas em tomate. 
Contudo, devido a seus componentes não serem tóxicos para adultos, eles não são úteis na redução da incidência de viroses transmitidas por B. tabaci (Palumbo et al., 2001). Liu (2004) observou uma significante redução na contaminação com "fumagina" das folhas e frutos de melão em plantas tratadas com spiromesifen. No entanto, em plantas tratadas com duas aplicações de thiamethoxan e buprofezin esta redução foi mínima.

Assim, o uso de produtos mais seletivos como os IGRs, para suprimir populações de B. tabaci pode auxiliar na conservação de populações de alguns predadores e parasitóides, quando comparado ao uso de inseticidas convencionais em alguns sistemas de cultivo (Palumbo et al., 2001). Também, foi observado por Liu (2004) durante experimento realizado em campo com melão, o grande parasitismo de Eretmocerus spp. e Encarsia spp. em plantas tratadas com spiromesifen, sugerindo baixo ou nenhum efeito sobre estes parasitóides.

Alguns estágios do ciclo de vida da mosca-branca são muito susceptíveis ao controle biológico utilizando predadores, parasitóides e patógenos, segundo Ahmad et al. (2001). Assim, para conservar, os insetos benéficos e reduzir o número de pulverizações, atrasos nas pulverizações subseqüentes devem ser realizados quando possível.

\subsection{Controle biológico de B. tabaci}

Um grande número de inimigos naturais são encontrados associados ou atacando B. tabaci. Gerling et al. (2001) catalogou 114 artrópodos predadores de B. tabaci pertencentes a 9 ordens e 31 famílias. Muitos predadores são generalistas, e avaliações reais de predação são extremamente difíceis em condições de campo, enquanto que, para parasitóides que atacam B. tabaci, esta avaliação é mais simples. Há uma estimativa incluindo 34 espécies de Encarsia (Hymenoptera: Aphelinidae), 14 espécies de Eretmocerus (Hymenoptera: Aphelinidae) e muitas espécies pertencentes aos gêneros Amitus (Hymenoptera: Platygasteridae) e Metaphycus (Hymenoptera: Encyrtidae) parasitando B. tabaci (Naranjo, 2001). Também foi descrito um 
hiperparasitóide em mosca-branca do gênero Signiphora spp. (Hymenoptera: Signiphoridae).

O gênero Encarsia inclui mais de 200 espécies descritas. Suas fêmeas desenvolvem-se em moscas-brancas ou cochonilhas de carapaça, enquanto os machos, além se desenvolverem nos mesmos hospedeiros das fêmeas, podem ainda completar seu ciclo em afelinídeos (como parasitóides secundários), ou ainda em ovos de lepidópteros ou outros hospedeiros (Gerling et al., 2001). Entretanto, o gênero Eretmocerus compreende somente parasitóides de mosca-branca.

Os gêneros Encarsia, Eretmocerus e Amitus são solitários, e com a exceção do primeiro ínstar de Eretmocerus, desenvolvem-se internamente no hospedeiro. Todos parasitam ninfas de mosca-branca e emergem do quarto ínstar morto do aleirodídeo. Encarsia e Eretmocerus atacam, principalmente, do segundo ao quarto ínstar do hospedeiro, enquanto Amitus prefere ovipositar em ninfas de primeiro ínstar (Gerling et al., 2001).

Segundo van Lenteren (2000), Bemisia spp. pode ser freqüentemente controlada pela introdução de misturas de Encarsia formosa e Eretmocerus eremicus (norte da Europa e América do Norte) ou Eretmocerus mundus (Mediterrâneo). O predador Macrolophus caliginosus (Hemiptera: Miridae) é, geralmente, adicionado aos parasitóides. Assim, com a introdução de dois parasitóides e um predador, melhores resultados de controle são obtidos por um período mais prolongado em casas-devegetação.

O predador Delphastus catalinae (Coleoptera: Coccinellidae) (anteriormente identificado como Delphastus pusillus) alimenta-se de formas imaturas de moscasbrancas. Mas ainda há dados conflitantes em relação a taxa de consumo de presas e se a oviposição pode ser afetada pelo consumo de diferentes estágios de mosca-branca. A reprodução destas espécies está intimamente associada às altas densidades de moscasbrancas. Desta maneira, D. catalinae pode não persistir com baixas populações de mosca-branca, e sua capacidade de se alimentar de presas alternativas como ácaros rajados pode ser crucial para a sua sobrevivência. No entanto, Nephaspis oculatus (Coleoptera: Coccinelidade) consome um menor número de moscas-brancas, podendo 
assim sobreviver e reproduzir-se em condições de baixas densidades do inseto (Gerling et al., 2001). De acordo com esses autores, o potencial de controle biológico de poucas espécies de predadores tem sido estudado, como por exemplo: D. catalinae e Serangium parcesetosum (Coleoptera: Coccinellidae), M. caliginosus, Chrysoperla carnea e Chrysoperla rufilabris (Neuroptera: Chrysopidae).

Em estudos feitos por Oliveira et al. (2003), em Brasília (DF), foram identificados cerca de 14 predadores, 12 parasitóides e 2 hiperparasitóides atacando $B$. tabaci e Trialeurodes vaporariorum em diferentes culturas. E. formosa foi encontrada em 40,2\% das amostras, seguida por Encarsia hispida, que ocorreu em 7,1\% das amostras, parasitando ambas espécies de moscas-brancas. Entre os parasitóides, Encarsia inaron ainda não havia sido registrada na América do Sul, e Encarsia basicincta é um novo registro para o Brasil. Em relação aos predadores, o besouro Nephaspis gemini foi observado em 14,8\% das amostras, predando ovos e ninfas de ambas espécies de moscas-brancas. Também foram registrados pela primeira vez, predando B. tabaci, os besouros Nephaspis hydra e Delphastus davidsoni.

Recentemente a produção e comercialização de inimigos naturais têm crescido muito. A Europa possui cerca de 26 produtores de inimigos naturais, incluindo os três maiores do mundo, sendo que em todo o mundo já existem cerca de 65 produtores (van Lenteren, 2000). A produção massal de inimigos naturais se desenvolveu muito rapidamente durante as três últimas décadas. Além do crescimento no número de produtores, o número de espécies disponíveis no mercado tem aumentado expressivamente, e uma visível evolução nos métodos de produção massal também tem sido observada.

\subsubsection{Controle microbiano}

Um grande número de patógenos são conhecidos e podem ser utilizados como forma de controle para diversas pragas, tais como rickétsias, vírus, bactérias, protozoários, nematóides e fungos. Contudo, segundo Faria \& Wraight (2001), as 
moscas-brancas não são susceptíveis à vários tipos de patógenos, como bactéria e vírus, devido sua alimentação ser realizada diretamente nos feixes vasculares das plantas.

Entretanto, em trabalho publicado por Hunter et al. (2001) um tipo de iridovirus foi isolado de células de B. tabaci biótipo B coletadas do campo, e foi denominado de “Insect Iridescent Virus 6”. Outros tipos de iridoviroses em insetos têm sido relatados como de grande importância econômica quando infectam pragas. Contudo, o modo de transmissão e persistência de iridoviroses em moscas-brancas ainda não é conhecido (Williams, 1996 citado por Hunter et al., 2001). Uma das hipóteses de transmissão seria por meio de grandes quantidades de excreção ou "honeydew" deixados sobre folhas, possibilitando a contaminação de outras moscas-brancas no momento da alimentação. Porém, ainda faltam testes para comprovar o modo de transmissão dos mesmos em moscas-brancas.

Levantamentos têm demonstrado que muitos fungos entomopatogênicos estão entre os inimigos naturais mais importantes dos aleirodídeos. São raras as ocorrências de espécies de Entomophthorales atacando B. tabaci, segundo Steinkraus et al. (1998) citado por Faria \& Wraight (2001). Zoophthora (= Erynia) radicans foi relatada atacando B. tabaci em Israel e Chade. Em trabalho de Sanchez-Peña (2000), folhas de feijão contendo ninfas de segundo e terceiro ínstar de Trialeurodes vaporariorum foram submetidas a infecção por Z radicans. O fungo causou infecção para $71 \%$ das ninfas expostas, e foi capaz de completar a sua reprodução assexuada (de conídio a conídio) sobre este hospedeiro. Contudo, o uso de Z. radicans e outros Entomophthorales como um agente de controle biológico tem apresentado muitas dificuldades, devido às grandes exigências desse fungo durante o processo de produção.

Muitas informações sobre infecções naturais por fungos em Bemisia spp. referem-se às espécies de hifomicetos, especialmente Paecilomyces spp., Verticillium spp. e Aschersonia spp. Dentre os patógenos mais comuns de mosca-branca ocorre Aschersonia, que possui um reduzido número de hospedeiros, limitando-se a moscabranca e coccídeos. Em contraste, com um número relativamente grande de hospedeiros estão os fungos Beauveria, Paecilomyces, Metarhizium e Verticillium (Faria \& Wraight, 2001). 
Epizootias de Aschersonia aleyrodis têm sido descritas em populações de $B$. tabaci atacando principalmente o estágio ninfal, embora as tentativas de controle microbiano com este fungo têm sido realizadas, segundo Faria \& Wraight (2001), visando T. vaporariorum. Além de A. aleyrodis outras espécies do gênero Aschersonia têm sido relatadas em espécies de moscas-brancas em todo o mundo. Cerca de 23 espécies de Aschersonia foram descritas em moscas-brancas, mas pouco é conhecido sobre seu controle efetivo sobre B. tabaci biótipo B e T. vaporariorum em cultivos protegidos. Pesquisas preliminares indicaram A. aleyrodis como um importante agente de controle, devido a sua tolerância a baixas umidades relativas (cerca de 50\%), além de possuir longa persistência sobre as folhas e ser compatível com E. formosa (Meekes et al., 2002).

Em certas condições, epizootias de fungos entomopatogênicos podem eliminar populações de B. tabaci (Landa et al., 1994; Lourenção et al., 1999; Lourenção et al., 2001). Entretanto, de modo geral, epizootias naturais nem sempre podem ser confiáveis como forma de controle. Somente poucas espécies de fungos têm a capacidade de causar altos níveis de mortalidade e o desenvolvimento de epizootias naturais não depende somente de condições ambientais. Várias práticas agrícolas podem levar à não ocorrência da epizootia (Faria \& Wraight, 2001).

Em experimentos realizados por Meekes et al. (2002) com ninfas de terceiro ínstar de B. argentifolii e T. vaporariorum, foram testados 31 isolados de Aschersonia spp.. Os níveis de infecção variaram entre 2 e $70 \%$, e as porcentagens de infecção de $B$. argentifolii foram semelhantes às obtidas com $T$. vaporariorum.

O fungo Paecilomyces farinosus também já foi identificado ocorrendo naturalmente em B. tabaci na Índia e Estados Unidos. Em testes feitos por Wraight et al. (1998) com isolados de $P$. farinosus foi comprovada sua patogenicidade sobre ninfas de B. argentifolii, mas a alta virulência encontrada nos isolados testados pode ser incomum.

Segundo Wraight et al. (2000), o fungo Paecilomyces fumosoroseus é considerado, mundialmente, como um dos mais importantes inimigos naturais de Bemisia spp. e Trialeurodes spp., com grande potencial epizoótico em casa-devegetação e em campo. Este patógeno infecta todos os estágios das moscas-brancas, 
incluindo os ovos. Resultados com altos níveis de mortalidade em moscas-brancas tratadas com $P$. fumosoroseus têm sido obtidos mais rapidamente do que nos insetos tratados com Verticillium lecanii ou B. bassiana.

$\mathrm{Na}$ temperatura de $30^{\circ} \mathrm{C}$, comprovou-se o desenvolvimento mais rápido e aumento nos valores do índice de crescimento dos fungos no inseto. Observou-se desenvolvimento extremamente lento quando um isolado de $P$. fumosoroseus (PFR 97) foi testado a $12^{\circ} \mathrm{C}$. Entretanto, o valor do índice de crescimento do fungo aumentou durante o período do ensaio. Com o decréscimo na umidade, ocorreu uma significativa inibição na germinação dos fungos no inseto hospedeiro. Assim, o fator limitante observado para a aplicação do isolado PFR 97 foi a umidade relativa (Landa et al., 1994).

Segundo Gindin et al. (2000) a infecção de insetos por micoinseticidas é afetada por vários parâmetros, incluindo temperatura, umidade, idade, e condição fisiológica do hospedeiro e patógeno. Um fator crítico que parece influenciar a patogenicidade dos fungos é a densidade populacional do inseto. Densidades populacionais irregulares sobre diferentes folhas podem modificar o microambiente no qual as interações entre o hospedeiro e patógeno podem ser alteradas. Por exemplo, altas densidades populacionais podem aumentar o desempenho dos patógenos facilitando seu desenvolvimento e disseminação entre os insetos, devido ao aumento na abundância de "honeydew". Em experimento realizado com $V$. lecanii (isolado Is-5) sobre ninfas de terceiro ínstar de $B$. tabaci biótipo B, a mortalidade aumentou de 34,4\% em baixas densidades para 100\% em altas densidades, sendo a variação da densidade de 2,5 a 25 insetos $/ \mathrm{cm}^{2}$.

Em testes realizados em laboratório com $V$. lecanii sobre “pupas” de $B$. argentifolii foi registrada infecção após 3 a 4 dias da inoculação. A mortalidade de “pupas” no quarto dia variou de 4,9 $\pm 2 \%$ no isolado Is-1 a $22,1 \pm 6 \%$ no isolado Is-5. Um aumento substancial na mortalidade de "pupas” foi observado entre o quarto e sétimo dia após a inoculação. Portanto a proporção de mortalidade causada por diferentes isolados

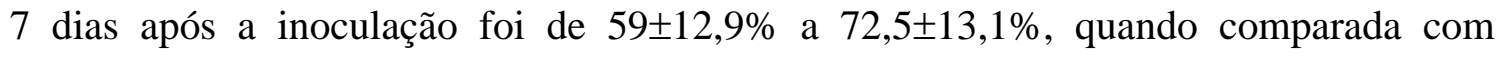
$13,5 \pm 4 \%$ da mortalidade na testemunha. Muitos adultos morreram antes ou durante a emergência das “pupas”. A proporção de adultos emergidos de “pupas” infectadas pelo 
isolado Is-2 foi de $27 \pm 13,1 \%$, quando comparado com $41 \pm 12,1 \%$ emergidos de "pupas" infectadas por $V$. lecanii isolado do produto comercial Mycotal. A proporção de adultos apresentando micose foi de $34,1 \pm 5,1 \%$ a $52,6 \pm 3,8 \%$ do total de adultos emergidos (Gindin et al., 2000).

Fungos entomopatogênicos precisam de umidade relativa e temperatura adequada para que possa ocorrer infecção e produção de conídios no inseto hospedeiro (Rombach \& Gillespie, 1988). Para obter um rápido desenvolvimento dos fungos $V$. lecanii e A. aleyrodis foi necessária $100 \%$ de umidade relativa logo após a aplicação dos fungos por um período de 12 horas. A flutuação na umidade relativa durante as primeiras 24 horas após a aplicação resultou em uma menor taxa de desenvolvimento do fungo.

Lourenção et al. (2001) registrou uma epizootia de $V$. lecanii em B. tabaci biótipo B em cultura de soja na cidade de Balsas, Estado do Maranhão. Isto ocorreu após um período de precipitação, onde a umidade relativa passou de $45 \%$ para $90 \%$ e ausência de ventos. Esta epizootia levou a níveis extremamente baixos a população de mosca-branca da área.

Pesquisas em controle de pragas de casas-de-vegetação utilizando fungos entomopatogênicos concentram-se no uso de $V$. lecanii e A. aleyrodis. $V$. lecanii possui uma extensa gama de hospedeiros parasitando afídeos, moscas-brancas, tripes e ácaros. $O$ uso de $V$. lecanii para o controle de mosca-branca em tomate tem produzido resultados variáveis, provavelmente devido à redução da umidade quando comparada em sistema de produção de pepino (Rombach \& Gillespie, 1988).

Condições climáticas favoráveis são essenciais para a ocorrência de epizootias, causando altos níveis de mortalidade. O manejo das condições de temperatura e umidade relativa constitui um fator importante no MIP em culturas em casa-de-vegetação, pois contribui para o desempenho de micoinseticidas (Vidal et al., 1998).

O fungo entomopatogênico B. bassiana não é considerado um regulador natural de populações de mosca-branca. Contudo, algumas pesquisas referem-se a indivíduos de Bemisia spp. infectados com este fungo, quando aplicado diretamente como uma suspensão concentrada de conídios (Wraight et al., 1998). Atualmente muitos produtos 
comerciais têm como princípio ativo $B$. bassiana, e muitos estão sendo ainda desenvolvidos em todo o mundo (Wraight et al., 2000). Seu potencial comercial é atribuído à facilidade de produção massal, compatibilidade com formulações de ingredientes ativos amplamente utilizados, incluindo óleos, emulsificantes e surfactantes, grande ação contra uma variedade de pragas agrícolas, e principalmente inocuidade à vertebrados.

Em pesquisa realizada em laboratório por Ramos (2001), a porcentagem de mortalidade de ninfas infectadas por B. bassiana variou de 2 a $70 \%$, sendo o isolado ESALQ 447 o mais eficiente. Estudos demonstram o significativo potencial do uso de alguns isolados selecionados desse fungo em laboratório, casa-de-vegetação e campo (Fransen, 1990).

Em testes de campo feitos por Wraight et al. (2000) com isolados de $B$. bassiana e $P$. fumosoroseus, todos os tratamentos com os fungos causaram altos níveis de mortalidade em ninfas de moscas-brancas. As ninfas mortas pelos fungos secaram rapidamente e permaneceram imóveis na folha. O crescimento externo e esporulação do fungo nos hospedeiros ocorreram somente durante extensos períodos de chuva ou no final dos experimentos, depois de muitas noites de exposição a condições de alta umidade. Em contraste, os efeitos em adultos de moscas-brancas foram mínimos.

James et al. (2003), descobriram que ambos os fungos, B. bassiana e $P$. fumosoroseus, tiveram níveis de virulência similares em testes realizados com $B$. argentifolii, embora tenha havido diferença de susceptibilidade entre os ínstares. $\mathrm{O}$ segundo e o terceiro ínstares foram os estágios mais susceptíveis à B. bassiana, e o segundo ínstar foi o mais susceptível à $P$. fumosoroseus.

Ramos et al. (2000), não observaram colonização de ovos de B. tabaci por $B$. bassiana (isolado ESALQ PL63) em testes realizados em laboratório. Em testes realizados por Gindin et al. (2000) com ovos de B. argentifolii, constatou-se que estes foram imunes a $V$. lecanii. Contudo, em estudos preliminares com população de diferentes estágios, os ovos que foram encontrados nas proximidades de ninfas e adultos infectados, puderam ser recobertos por hifas do fungo. Embora o córion destes ovos não tenha sido invadido por nenhum isolado testado, nos ovos cobertos com hifas, as ninfas 
não eclodiram ou eclodiram com um atraso de 3 a 4 dias. Ainda, as hifas presentes sobre os ovos foram encontradas infectando as ninfas recém-eclodidas.

O fungo M. anisopliae causou mortalidade em B. tabaci entre 34 a 90\%, sendo o isolado ESALQ E9 o mais eficiente. A partir do terceiro dia após a inoculação, $M$. anisopliae ocasionou aproximadamente $30 \%$ de mortalidade, sendo o pico da mortalidade observado ao quinto dia. A suscetibilidade das ninfas a isolados de $M$. anisopliae foi evidente nos experimentos, sendo essa espécie de fungo promissora para o controle de ninfas (Ramos 2001).

O efeito rápido de $M$. anisopliae no controle de altas populações de Bemisia spp. é uma característica importante e desejável no controle de espécies transmissoras de vírus, como é o caso do biótipo B, tornando-se necessário o controle imediato da praga (Hilje et al., 1998).

Segundo Kleespies \& Zimmermann (1994), a patogenicidade de B. bassiana e M. anisopliae pode variar sobre ninfas, e este fato pode ser atribuído à variabilidade genética das linhagens dos fungos, produção de enzimas, toxinas, aderência, velocidade de germinação dos conídios e conseqüente penetração na cutícula das ninfas e capacidade de colonização dos isolados.

Os fungos entomopatogênicos podem ser produzidos e aplicados facilmente e sua utilização é semelhante a de outros inseticidas utilizados pelos agricultores, o qual lhes promove uma alternativa prática e viável para o controle de vetores, além de ser possível a complementação com o controle químico (Alves et al. 1998c; Ramos et al. 2000).

\subsubsection{Controle associado}

A conservação é uma estratégia prática e economicamente viável dentro dos agroecossistemas. Pode ser feita pela adoção de técnicas agronômicas simples, tais como adequação do espaçamento, utilização de variedades com arquitetura de planta favorável ao patógeno e também pela aplicação de agrotóxicos seletivos a entomopatógenos. 
Durante muitas décadas pesquisadores de todo o mundo têm avaliado o efeito tóxico de inseticidas sobre inimigos naturais de vários insetos-pragas. Os estudos visando detectar os efeitos de agrotóxicos sobre entomopatógenos iniciaram-se depois da Segunda Guerra Mundial, com a utilização de produtos organoclorados em larga escala. No entanto, as indústrias que desenvolvem os defensivos agrícolas normalmente não testam a sua toxicidade para os entomopatógenos, referindo a seletividade das formulações apenas a parasitóides e predadores (Alves et al., 1998c).

A maioria dos trabalhos realizados visando detectar o efeito de produtos fitossanitários sobre entomopatógenos é referente a fungos entomopatogênicos, e a quase totalidade desses trabalhos foi conduzida in vitro.

A falta de dados referentes às interações entre os entomopatógenos e agrotóxicos em condições de campo, é outro fato a ser observado. Testes deste tipo exigem um estudo mais aprimorado, levando em conta: 1) a presença de inóculo natural na área a ser avaliada, sua amostragem e identificação; 2) introdução e posterior avaliação do inóculo a ser estudado, permitindo a observação da cinética do desenvolvimento do patógeno na área, sob influência da ação do produto químico. Além disso, é importante um bom acompanhamento das condições atmosféricas, para que se possa visualizar a existência de correlações entre o desenvolvimento e/ ou permanência do patógeno e os fatores ambientais, procurando-se isolá-los, para avaliar somente o efeito do produto químico sobre o patógeno (Alves et al, 1998a).

Em trabalho de Alves et al. (2001) em plantas de feijão, a aplicação de $B$. bassiana em associação com o inseticida Calypso 480 SC nas concentrações de 50 e 100 $\mathrm{mL} / \mathrm{ha}$ proporcionou redução de 90,7 e 83,6\% no número de ninfas de B. tabaci, respectivamente. Esses valores foram superiores ao apresentado pelo produto químico na sua maior dosagem (200 mL/ha), quando se observou redução de 65,9\%. A redução da concentração do inseticida Calypso em 50 e 75\%, além de representar economia e menor poluição, resulta em menor pressão de seleção para o desenvolvimento de resistência na população da praga.

O uso de concentrações subletais (subconcentrações) é uma estratégia que permite reduzir a quantidade e o custo com o inimigo natural, a quantidade de resíduos 
químicos sobre os alimentos e a possibilidade de intoxicação dos trabalhadores rurais durante os processos de preparo da calda inseticida e sua aplicação (Tamai et al., 2002).

Devido a este fato, muitos autores têm realizado testes de compatibilidade in vitro com diversos produtos químicos e fungos entomopatogênicos. Nesses testes são avaliados os efeitos dos produtos, principalmente, sobre o crescimento vegetativo e esporulação (número de conídios).

\subsubsection{Avaliação da toxicidade de agrotóxicos}

A avaliação da toxicidade de agrotóxicos é importante para orientar os usuários na escolha de produtos mais adequados para condução de um controle sustentável de pragas.

Assim, a metodologia utilizada em testes de compatibilidade e classificação da toxicidade dos produtos têm sofrido variações no decorrer dos anos. Em experimento realizado por Hall \& Dunn (1959) os produtos químicos foram misturados ao meio de cultura SDA (Sabouraud Dextrose Agar) fundido e depois inoculados cinco espécies do fungo Entomophthora com o auxílio de uma alça de platina. As placas da testemunha e dos tratamentos foram incubadas por 10 dias em sala climatizada com temperatura aproximada de $24^{\circ} \mathrm{C}$. Somente o crescimento vegetativo dos fungos foi observado para posterior classificação. Assim, as observações foram registradas como: 1) nenhum crescimento; 2) pouco crescimento somente do inóculo; 3) moderado crescimento do inóculo no substrato; e 4) bom crescimento do inóculo no substrato quando comparado ao crescimento dos fungos na testemunha. O não crescimento foi considerado como indicador que o material foi tóxico aos fungos. O crescimento somente do inóculo indicou que o material incorporado foi inibitório. O crescimento no substrato indicou que o produto químico teve pouco ou nenhum efeito sobre os fungos.

Li \& Holdom (1994) utilizou uma metodologia semelhante a de Hall \& Dunn (1959), mas além do crescimento vegetativo, a esporulação do fungo também foi avaliada. O para determinar o crescimento vegetativo, após 10 dias de incubação, foi utilizado um medidor de crescimento micelial. Depois de medido o diâmetro das 
colônias, $5 \mathrm{~mL}$ de etanol a $75 \%$ foi colocado em cada placa para matar e umedecer os conídios. As placas foram então lavadas 10 vezes com 9,5 mL de Tween 80 a 0,05\%, sendo esta suspensão recolhida em fracos para posterior sonicação. Então, o número de conídios foi determinado com o auxílio de um hematocitometro. Os dados obtidos foram submetidos a uma análise de variância, sem posterior classificação do nível de toxicidade dos produtos.

Para determinar o crescimento linear e a esporulação de B. bassiana, Todorova et al. (1998), produziu em meio SDA inóculo de B. bassiana, sendo este mantido a $24^{\circ} \mathrm{C}$ por 20 dias. Em placas de Petri de $10 \mathrm{~cm}$ de diâmetro foram colocados $25 \mathrm{~mL}$ da mistura de meio SDA com os produtos testados. Uma pequena porção (1 $1 \mathrm{~mm}$ de profundidade, 7 mm de diâmetro) de SDA com B. bassiana, foi depositado no centro de cada placa de Petri contendo a mistura de SDA com os produtos. Estas placas foram incubadas a $24^{\circ}$ C, e o crescimento linear que excedeu a porção anteriormente colocada, foi medida no $7^{\circ}, 10^{\circ}$ e $14^{\circ}$ dia após o início de experimento. O crescimento foi medido com o auxílio de uma régua milimétrica em 4 pontos cardinais da pequena porção, sendo o valor médio utilizado para as análises estatísticas. Após 14 dias, os conídios que foram produzidos a partir do excesso da porção inicialmente colocada, foram retirados através de raspagem e suspendidos em $1 \mathrm{~mL}$ de solução salina. A concentração de conídios foi estimada usando um hemacitômetro.

Como pode ser observada, uma das dificuldades encontrada é a falta de padronização nos testes para avaliação da toxicidade destes produtos químicos aos entomopatógenos, impedindo a comparação efetiva entre os resultados obtidos em diversas partes do mundo. Uma tentativa de padronização foi realizada por Alves et al. (1998a) e representa uma importante forma de avaliação do efeito tóxico in vitro de produtos químicos aos patógenos. Os produtos são adicionados ao meio BDA (Batata Dextrose Agar) fundido e este colocado em placas de Petri. Os fungos são inoculados, com uma alça de platina, em três pontos eqüidistantes da placa, sendo esta incubada por aproximadamente 7 a 10 dias em temperatura constante. São avaliados o crescimento vegetativo, medindo-se o diâmetro das colônias e a esporulação com o auxílio de um hematocitômetro. Os valores encontrados são corrigidos em relação a testemunha e estão 
aplicados a uma expressão matemática para determinar o nível de toxicidade dos produtos testados.

Neste tipo de teste o patógeno é exposto ao máximo à ação dos produtos, o que não ocorre em condições de campo. Por outro lado, quando esses produtos são compatíveis in vitro há forte evidência de sua seletividade em condições de campo. Contudo, níveis elevados de toxicidade in vitro não podem ser considerados bons indicadores para o comportamento do produto em condições de campo, embora mostre uma possibilidade de que isto possa ocorrer (Moino Jr. \& Alves, 1998; Alves et al., 2001; Batista Filho et al., 2001; Neves et al., 2001; Loureiro et al., 2002).

No entanto, a germinação dos fungos têm sido considerada atualmente, por muitos autores, como o parâmetro mais importante nos testes de compatibilidade (Anderson \& Roberts, 1983; Malo, 1993; Neves et al. 2001; Oliveira et al., 2003). Isto ocorre, pois os fungos entomopatogênicos infectam os insetos através da germinação dos conídios, seja por ingestão, ou por contato. A preservação dos fungos em campo (inóculo) também ocorre, principalmente, na forma de conídio. No início de uma epizootia, o conídio é responsável pela ocorrência do primeiro foco da doença. Assim, se ocorrer uma inibição da germinação, a eficiência de controle pelo patógeno será comprometida se este tiver sido aplicado de forma inundativa, junto ou separadamente com o produto químico. Um mesmo comprometimento ocorrerá se este patógeno estiver naturalmente presente na área e em contato com o produto (Neves et al., 2001).

As ações dos produtos fitossanitários sobre os entomopatógenos podem variar em função da espécie e linhagem do patógeno, da natureza química dos produtos e das dosagens utilizadas (Alves et al., 1998a). Muitos pesticidas testados por Landa et al. (1994) inibiram alguma fase do crescimento dos fungos, particularmente o crescimento de micélio no hospedeiro e a conidiogênese.

O modo de ação do ingrediente ativo é possivelmente um dos principais fatores envolvidos no nível de toxicidade dos produtos fitossanitários aos fungos entomopatogênicos. Embora os inseticidas e/ ou acaricidas atuem, de modo geral, em pontos específicos da fisiologia de insetos e ácaros (Omoto, 2000), o modo de ação não determina que estes produtos sejam seletivos a B. bassiana e M. anisopliae. Outros 
fatores podem estar envolvidos, como os sítios secundários de ação, quantidade e componentes da formulação e sua capacidade de alterar o pH do meio de cultura (Tamai et al., 2002). Anderson \& Roberts (1983) apontam que a formulação do inseticida pode ser mais importante que o próprio ingrediente ativo no efeito sobre os fungos. Contudo, a hipótese que o ingrediente ativo tenha um efeito fungitóxico não é descartada.

Embora muitos agentes químicos possam interferir negativamente na ação dos entomopatógenos, alguns produtos podem ser utilizados em associação com agentes microbianos de controle, por terem ação sinérgica ou aditiva com os mesmos. Esse procedimento, além de reduzir o número de aplicações de produtos químicos, concorrendo para a menor poluição ambiental, pode melhorar o desempenho dos mesmos (Pereira et al., 1998).

Por isso é necessário conhecer produtos compatíveis ou de baixa toxicidade a inimigos naturais, pertencentes a diferentes grupos químicos, permitindo o manejo da resistência a produtos químicos das principais pragas das culturas, utilizando a técnica de rotação de produtos com diferentes modos de ação. Além disso, estes produtos podem ser utilizados em concentração máxima recomendada, na estratégia conhecida como manejo múltiplo, ou em subconcentrações (subdoses). Neste último caso, o produto químico poderia atuar como um sinergista do entomopatógeno, auxiliando a infecção fúngica por meio da ação estressora, tornando o inseto mais suscetível à ação do microrganismo (Batista Filho et al., 2001). Nessa estratégia, o controle proporcionado pelo produto químico e entomopatógeno em mistura deve ser superior a soma dos resultados de controle observados para cada uma destas táticas separadamente.

Visando tornar mais racional o uso desses parâmetros na classificação toxicológica das formulações de agrotóxicos, Alves et al. (1998c) propôs uma expressão matemática, onde utilizava os parâmetros crescimento vegetativo e esporulação para comparação com a testemunha, sem contudo estabelecer os intervalos de confiança das diferentes classes toxicológicas.

Por outro lado existe uma técnica de Jackknife para estabelecer intervalos de confiança em estudos de tabela de vida que vem sendo bastante utilizadas (Medeiros, 2002) que estabelece mais precisão aos resultados. 


\section{MATERIAL E MÉTODOS}

O trabalho foi desenvolvido no Laboratório de Patologia e Controle Microbiano de Insetos, do Departamento de Entomologia, Fitopatologia e Zoologia Agrícola da Escola Superior de Agricultura "Luiz de Queiroz", Universidade de São Paulo, em Piracicaba-SP, no período de janeiro de 2003 a setembro de 2004.

\subsection{Criação e manutenção de Bemisia tabaci em casa-de-vegetação}

Para a constituição da colônia estoque de B. tabaci, plantas de soja infestadas com ovos e ninfas do inseto foram mantidas em casas-de-vegetação no setor de Entomologia (ESALQ/USP).

A produção de insetos para os bioensaios foi feita utilizando plantas de soja (Glycine max L.) cultivar Embrapa 48, e durante alguns períodos do ano (abril a agosto), plantas de amendoim-bravo (Euphorbia heterophylla) também foram utilizadas. Essas plantas foram cultivadas em vasos plásticos com uma mistura de terra, areia e matéria orgânica. Cerca de sete sementes foram semeadas em cada vaso, sendo estes submetidos à infestação com, aproximadamente, 15 a 20 dias de idade. As plantas velhas e secas eram substituídas por plantas sadias de acordo com a intensidade de infestação e necessidade de reposição do substrato alimentar dos insetos.

\subsection{Toxicidade de produtos fitossanitários a $B$. bassiana e $M$. anisopliae}

Nestes testes foram utilizados isolados de duas espécies de fungos entomopatogênicos provenientes do banco de patógenos do Laboratório de Patologia e 
Controle Microbiano de Insetos, sendo um isolado de B. bassiana (ESALQ 447) e um de M. anisopliae (ESALQ E9). Estes isolados foram selecionados por Ramos (2001) como sendo altamente patogênicos a B. tabaci em condições de laboratório.

Os isolados foram inoculados em placas de Petri contendo meio de cultura MC (0,36 g Fosfato de potássio; 1,05 g Fosfato de sódio; 0,6 g Sulfato de magnésio; 1,0 g Cloreto de potássio; 10,0 g Glucose; 1,58 g Nitrato de sódio; 5,0 g Extrato de levedura; 20,0 g de Ágar; $1000 \mathrm{~mL}$ Água destilada; autoclavagem por 20 minutos a $120^{\circ} \mathrm{C}$ ), com o auxílio de um cabo de Kolle. Os conídios foram espalhados sobre o meio com uma alça de Drigalsky e posteriormente levados à câmara climatizada (B.O.D.) onde foram mantidos por 7 dias (Alves et al., 1998b), a $26 \pm 0,5^{\circ} \mathrm{C} ; 70 \pm 10 \%$ UR e fotofase de 12 horas para o crescimento e esporulação do fungo.

Os testes foram conduzidos in vitro, em meio de cultura BDA (20,0 g Ágar; 15,0 g Dextrosol; 200,0 g Batata; 0,5 g Streptomicina; 1000 mL Água destilada; autoclavagem por 20 minutos a $120^{\circ} \mathrm{C}$ ), acrescentando-se os produtos fitossanitários em concentrações pré-estabelecidas ao meio de cultura fundido com aproximadamente $40^{\circ}$ C. Foram avaliados 18 produtos fitossanitários (15 inseticidas e 3 fungicidas) (Tabela 1) pertencentes as diferentes classes toxicológicas e ingredientes ativos. Estes produtos têm sido utilizados no Brasil para o controle de B. tabaci e doenças fúngicas relacionadas, principalmente, à cultura de tomate. As concentrações utilizadas foram àquelas estabelecidas nos rótulos dos produtos.

Com a solidificação do meio de cultura contendo o produto foi efetuada a inoculação do fungo utilizando-se uma alça de platina contendo em sua extremidade conídios dos fungos. A inoculação foi feita em três pontos eqüidistantes entre si para evitar o contato entre as colônias após o crescimento.

Após a inoculação, as placas de Petri foram mantidas em câmara climatizada por 7 dias $\left(26 \pm 0,5^{\circ} \mathrm{C} ; 70 \pm 10 \%\right.$ UR e fotofase de 12 horas) para crescimento e esporulação do patógeno. Foram preparadas três placas por tratamento, totalizando nove colônias, das quais seis mais uniformes foram selecionadas para avaliação. 
Tabela 1. Descrição de inseticidas utilizados nos testes de toxicidade e concentração comercial utilizada (Andrei, 1999)

\begin{tabular}{|c|c|c|c|c|c|}
\hline Produto Comercial & Nome Técnico & $\begin{array}{c}\text { Classe } \\
\text { Toxicológica }\end{array}$ & Classe & Grupo Químico & $\begin{array}{c}\text { Concentração } \\
\text { Utilizada }\end{array}$ \\
\hline Actara $250 \mathrm{WG}$ & thiamethoxan & III & Inseticida sistêmico & Neonicotenóide & $20 \mathrm{~g} / 100 \mathrm{~L}$ \\
\hline Applaud 250 & buprofezin & IV & Inseticida regulador de crescimento & Tiadiazina & $200 \mathrm{~g} / 100 \mathrm{~L}$ \\
\hline Baythroid CE & cyfluthrin & III & Inseticida de contato & Piretróide & $40 \mathrm{~mL} / 100 \mathrm{~L}$ \\
\hline Bulldock 125 SC & betacyfluthrin & II & Inseticida de contato & Piretróide & $10 \mathrm{~mL} / 100 \mathrm{~L}$ \\
\hline Calypso & triacloprid & III & Inseticida sistêmico & Neonicotenóide & $20 \mathrm{~mL} / 100 \mathrm{~L}$ \\
\hline Cartap BR 500 & cartap & III & Inseticida fungicida & Tiocarbamato & $250 \mathrm{~g} / 100 \mathrm{~L}$ \\
\hline Cercobin 700 PM & tiofanato-metílico & IV & Fungicida sistêmico & Benzimidazol & $70 \mathrm{~g} / 100 \mathrm{~L}$ \\
\hline Confidor 700 GRDA & imidacloprid & IV & Inseticida sistêmico & Nitrogranidinas & $30 \mathrm{~g} / 100 \mathrm{~L}$ \\
\hline Cordial 100 & pyriproxyfen & II & Inseticida regulador de crescimento & Piril éter & $100 \mathrm{~mL} / 100 \mathrm{~L}$ \\
\hline Dithane PM & mancozeb & III & Fungicida e acaricida & Ditiocarbamato & $250 \mathrm{~g} / 100 \mathrm{~L}$ \\
\hline Kumulus DF & enxofre & IV & Fungicida e acaricida & Enxofre & $400 \mathrm{~g} / 100 \mathrm{~L}$ \\
\hline Malathion $1000 \mathrm{CE}$ & malation & III & Inseticida e acaricida & Organofosforado & $1 \mathrm{~mL} / 100 \mathrm{~L}$ \\
\hline Meothrin 300 & fenpropathrin & I & Inseticida e acaricida & Piretróide & $300 \mathrm{~mL} / 100 \mathrm{~L}$ \\
\hline Oberon 240 SC & spiromesifen & IV & Inseticida e acaricida regulador de crescimento & Ácido tetrônico & $50 \mathrm{~mL} / 100 \mathrm{~L}$ \\
\hline Orthene 750 BR & acefato & IV & Inseticida e acaricida sistêmico & Organofosforado & $100 \mathrm{~g} / 100 \mathrm{~L}$ \\
\hline Sumidan $25 \mathrm{CE}$ & esfenvalerate & I & Inseticida & Piretróide & $75 \mathrm{~mL} / 100 \mathrm{~L}$ \\
\hline Supracid 400 CE & methidathion & II & Inseticida & Organofosforado & $125 \mathrm{~mL} / 100 \mathrm{~L}$ \\
\hline Tamaron BR & metamidophos & II & Inseticida e acaricida sistêmico & Fosforado & $100 \mathrm{~mL} / 100 \mathrm{~L}$ \\
\hline
\end{tabular}




\title{
3.3 Classificação toxicológica dos agrotóxicos usando os parâmetros crescimento vegetativo, esporulação e germinação de fungos entomopatogênicos
}

\begin{abstract}
Para a determinação do efeito tóxico dos produtos foram avaliados os parâmetros crescimento vegetativo e reprodução do patógeno (conidiogênese) utilizando-se o modelo de classificação de produtos fitossanitários quanto à toxicidade sobre fungos entomopatogênicos proposto por Alves et al. (1998a). O crescimento vegetativo foi determinado medindo-se os diâmetros das colônias em dois sentidos na superfície do meio de cultura, considerando-se o diâmetro médio das mesmas. Para avaliar a reprodução do patógeno, essas colônias foram recortadas juntamente com o meio de cultura e transferidas individualmente para tubos de vidro contendo $10 \mathrm{~mL}$ de água destilada estéril mais espalhante adesivo (Tween $40^{\circledR}$ a $0,2 \%$ ). Os conídios presentes no meio foram removidos com o auxílio de um pincel e posteriormente homogeneizados em agitador de tubos e ultrasom, para sua quantificação em câmara de Neubauer.
\end{abstract}

A avaliação foi baseada no sistema de cálculo das porcentagens médias de conidiogênese (esporulação) e crescimento vegetativo das colônias de fungos, em relação à testemunha, aplicando-se o modelo matemático proposto por Alves et al. (1998a):

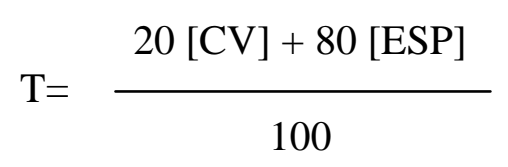

onde:

T: valor corrigido do crescimento vegetativo e esporulação para classificação do produto;

$\mathrm{CV}$ : porcentagem de crescimento vegetativo com relação à testemunha;

ESP: porcentagem de esporulação com relação à testemunha. 
De acordo com os valores que foram obtidos de "T", foi realizada uma comparação com os limites estabelecidos na Tabela 2, para determinação da toxicidade dos produtos estudados.

Tabela 2. Valores de T para classificação do efeito de produtos químicos sobre fungos (Alves et al., 1998a)

\begin{tabular}{cc}
\hline Valor de $\mathbf{T}$ & Classificação do produto \\
\hline 0 a 30 & Muito tóxico \\
31 a 45 & Tóxico \\
46 a 60 & Moderadamente tóxico \\
$>60$ & Compatível \\
\hline
\end{tabular}

Outro parâmetro analisado para a determinação da toxicidade dos produtos, foi o seu efeito sobre a germinação dos patógenos testados, segundo metodologia proposta por Neves et al. (2001). Neste teste, foram preparadas caldas dos produtos fitossanitários com água contendo espalhante adesivo (Tween $40^{\circledR}$ a $0,2 \%$ ). Suspensões dos fungos $B$. bassiana (ESALQ 447) e M. anisopliae (ESALQ E9) também foram feitas e adicionadas às caldas dos produtos químicos. Depois de uma hora, foram retiradas alíquotas de 0,1 $\mathrm{mL}$ de cada mistura - fungos (concentração $1 \times 10^{7}$ conídios/mL) + inseticida (dose comercial recomendada) -, sendo estas colocadas sobre placas de Petri contendo meio ágar-água (2\%) e espalhada com o auxilio de uma alça de Drigalsky. Estas placas foram mantidas por 24 horas em câmaras climatizadas a $26 \pm 0,5^{\circ} \mathrm{C} ; 70 \pm 10 \%$ UR e fotofase de 12 horas. Após esse período de incubação foi quantificada a porcentagem de germinação dos conídios, contando-se o número de conídios germinados e não-germinados com o auxílio de um microscópio óptico.

Os valores obtidos nos testes de esporulação, crescimento vegetativo e germinação foram submetidos a análise de variância para comparação de suas médias (Tukey $\mathrm{p}<0,05$ ). 
Visando uma classificação mais abrangente dos efeitos toxicológicos dos agrotóxicos sobre fungos entomopatogênicos, incluindo também a germinação, foi proposta uma nova expressão matemática:

$$
\mathrm{T}=\frac{\mathrm{X}[\mathrm{CV}]+\mathrm{Y}[\mathrm{ESP}]+\mathrm{Z}[\mathrm{GER}]}{100}
$$

Utilizaram-se a técnica de Jackknife para obtenção dos parâmetros e intervalos de confiança dessa expressão e o software SYSTAT para obtenção das estimativas, aplicando-se o teste $\mathrm{F}$ na seleção da influência de cada variável, determinado pela análise de agrupamento.

A classificação dos produtos foi feita baseada no intervalo de confiança (IC) do valor de $\mathrm{T}(\mathrm{P}=0,05)$ nas seguintes classes:
Abaixo do IC - Muito Tóxico
Dentro do IC - Tóxico
Acima do IC - Compatível

\subsection{Efeito de subdoses de spiromesifen sobre ninfas de B. tabaci}

O produto fitossanitário selecionado para os testes de subdose foi o spiromesifen. Foram utilizadas folhas de plantas de soja infestadas com ninfas de $3^{\circ}$ ínstar. Foi realizada a abscisão das folhas com o auxílio de um bisturi deixando cerca de $5 \mathrm{~cm}$ de pecíolo, o qual foi envolvido com algodão umedecido para evitar ressecamento precoce do material. Cada folha infestada foi transferida para placas de Petri $(15 \times 2 \mathrm{~cm})$ contendo uma camada de papel filtro circular no fundo. Para cada tratamento, foram preparadas cinco repetições contendo 20 ninfas/folhas, totalizando 100 insetos para cada tratamento, segundo metodologia de Ramos (2001). 
As pulverizações foram realizadas em Torre de Potter (Burkard Manufacturing Co. Ltd.), calibrada a 15 libras/pol ${ }^{2}$ de pressão, utilizando-se $2 \mathrm{~mL}\left(0,2 \mu \mathrm{l} / \mathrm{cm}^{2}\right)$ da calda dos produtos nas concentrações: 1) dose comercial recomendada (50 mL/100 L de água); 2) 75\% da dose comercial (37,5 mL/ 100 L de água); 3) 50\% da dose comercial (25 mL/100 L de água); 4) 25\% da dose comercial (12,5 mL/100 L de água) e 5) testemunha (água + espalhante adesivo Tween $40^{\circledR}$ a $0,2 \%$ ). As avaliações foram feitas diariamente, até o sétimo dia após a pulverização, registrando-se a mortalidade diária de ninfas em cada folha. Durante os dias de avaliação as placas contendo os insetos foram mantidas em câmaras climatizadas tipo B.O.D. a 26 $\pm 0,5^{\circ} \mathrm{C}$; $70 \pm 10 \%$ UR e 12 horas de fotofase, e molhadas diariamente para evitar ressecamento das folhas.

As porcentagens de mortalidade das ninfas de $B$. tabaci obtidas nos diferentes tratamentos foram submetidas a uma análise de variância para comparação de suas médias usando-se o teste de Tukey $(\mathrm{p}<0,05)$.

\subsection{Efeito de B. bassiana, M. anisopliae e spiromesifen sobre larvas de Delphastus} sp.

Durante o período em que foi mantida a criação de B. tabaci biótipo B para a realização deste trabalho, ocorreu uma grande ocorrência do predador Delphastus sp. (Coleoptera: Coccinellidae) atacando ninfas de mosca-branca. Com isso, Efetuou-se um bioensaio para se avaliar o efeito dos fungos entomopatogênicos $B$. bassiana e $M$. anisopliae e do produto fitossanitário spiromesifen, sobre larvas deste coccinelídeo.

Para a realização deste teste foram utilizadas folhas de plantas de soja infestadas com ninfas de $B$. tabaci biótipo $B$, que serviram de alimento para o coccinelídeo. Foi realizada a abscisão das folhas com o auxílio de um bisturi deixando cerca de $5 \mathrm{~cm}$ de pecíolo, o qual foi envolvido com algodão umedecido para evitar ressecamento precoce do material. Cada folha, infestada com ninfas foi transferida para placas de Petri $(15$ x $2 \mathrm{~cm})$ contendo uma camada de papel filtro circular no fundo. Sobre as folhas de soja, foram transferidas 21 larvas (7 em cada repetição) de diferentes ínstares de Delphastus sp. para cada tratamento. 
As pulverizações foram realizadas em Torre de Potter (Burkard Manufacturing Co. Ltd.), calibrada a 15 libras/pol ${ }^{2}$ de pressão, utilizando-se $2 \mathrm{~mL}\left(0,2 \mu \mathrm{l} / \mathrm{cm}^{2}\right)$ da suspensão dos produtos. Os tratamentos utilizados foram: 1) Boveril ${ }^{\circledR}$ PM (produto comercial a base de B. bassiana isolado ESALQ 447) na concentração de 2 Kg/ 100 Litros de água; 2) Metarril PM (produto comercial a base de $M$. anisopliae isolado ESALQ E9) na concentração de $2 \mathrm{Kg} / 100$ Litros de água; 3) Boveril ${ }^{\circledR}$ PM na concentração de $2 \mathrm{Kg} / 100$ Litros de água mais o produto fitossanitário spiromesifen na concentração de 25 mL/ 100 Litros de água; 4) Metarril PM na concentração de 2 Kg/ 100 Litros de água mais o produto fitossanitário spiromesifen na concentração de 25 mL/ 100 Litros de água; 5) Produto fitossanitário spiromesifen na concentração de 25 mL/ 100 Litros de água e 6) Testemunha que recebeu apenas água mais espalhante adesivo (Tween $40^{\circledR}-0,2 \mathrm{~mL} / \mathrm{L}$ ).

As avaliações foram feitas diariamente, até o quinto dia após a pulverização, registrando-se a mortalidade diária das larvas em cada tratamento. Durante os dias de avaliação as placas contendo os insetos foram mantidas em câmaras climatizadas tipo B.O.D. a $26 \pm 0,5^{\circ} \mathrm{C}, 70 \pm 10 \%$ UR e 12 horas de fotofase, e molhadas diariamente para evitar ressecamento das folhas.

\subsection{Efeito da associação de spiromesifen e fungos entomopatogênicos sobre ninfas de B. tabaci em tomateiros sob cultivo em estufa}

Este teste foi conduzido em condições de semi-campo, na estufa do Laboratório de Patologia e Controle Microbiano de Insetos durante o período de abril a agosto de 2004.

Para a realização deste teste foram utilizadas sementes não-tratadas de tomate (Lycopersicum esculentum, L., cv. Bruna), que foram plantadas em sementeiras

contendo substrato vegetal. Aproximadamente 20 dias depois do plantio, foi realizado o transplante das mudas. Para isso, foram utilizados 30 vasos (5 para cada tratamento) de plástico de 20 Litros, contendo uma mistura de terra, areia, matéria orgânica e NPK, onde foram transplantadas duas mudas de tomate em cada vaso. Os vasos, com os 
tratamentos pré-determinados, foram distribuídos de maneira aleatória no interior da casa-de-vegetação. Após o transplante, as mudas foram infectadas com adultos de $B$. tabaci.

Durante a primeira semana foram realizadas três avaliações para determinar a infecção inicial de adultos de B. tabaci por planta. Após esse período foi realizada a primeira pulverização das plantas. Os tratamentos utilizados foram: 1) Boveril $^{\circledR} \mathrm{PM}$ (produto comercial a base de B. bassiana isolado ESALQ 447) na concentração de 2 Kg/ 100 Litros de água; 2) Metarril PM (produto comercial a base de M. anisopliae isolado ESALQ E9) na concentração de $2 \mathrm{Kg} / 100$ Litros de água; 3) Boveril ${ }^{\circledR}$ PM na concentração de $2 \mathrm{Kg} / 100$ Litros de água mais o produto spiromesifen na concentração de 25 mL/ 100 Litros de água; 4) Metarril PM na concentração de 2 Kg/ 100 Litros de água mais o produto spiromesifen na concentração de 25 mL/ 100 Litros de água; 5) Produto spiromesifen na concentração de 25 mL/ 100 Litros de água e 6) Testemunha que recebeu apenas água mais espalhante adesivo (Tween $40^{\circledR}-0,2$ $\mathrm{mL} / \mathrm{L}$ ). As suspensões de conídios com viabilidade conhecida foram preparadas com os produtos comerciais, adicionando-se água destilada estéril mais espalhante adesivo (Tween $40^{\circledR}-0,2 \mathrm{~mL} / \mathrm{L}$ ). Após o preparo das suspensões adicionou-se o spiromesifen, sendo incorporado à calda por agitação, para posterior pulverização.

Após o transplante, durante 21 dias, foram realizadas três pulverizações por semana, com o auxílio de um micropulverizador manual PulverJet P500, totalizando 10 aplicações, pois durante a fase inicial de desenvolvimento, as plantas de tomate são mais susceptíveis e o dano causado por B. tabaci é muito mais crítico. Depois deste período, as pulverizações passaram a ser semanais, sendo realizadas mais 8 aplicações, totalizando 18 aplicações.

Nas quatro primeiras avaliações, após o início das pulverizações, foi observado apenas o número de adultos presentes nas plantas de cada vaso, pois a abscisão de folhas poderia prejudicar as mudas. Estas avaliações foram realizadas semanalmente. As avaliações seguintes foram efetuada quinzenalmente, retirando-se aleatoriamente folhas tratadas das plantas de tomate, para sua observação em esterioscópio e determinação do número de ninfas vivas e mortas presentes nas folhas. Esta avaliação 
foi realizada observando-se toda a face inferior das folhas, local de preferência para oviposição da mosca-branca, e contando o número de ninfas em cada tratamento. 


\section{RESULTADOS E DISCUSSÃO}

\subsection{Criação e manutenção de $B$. tabaci em casa-de-vegetação}

Durante a manutenção da colônia estoque de $B$. tabaci, em plantas de soja, durante alguns períodos do ano a população deste inseto manteve-se muito alta, principalmente nos períodos mais quentes e secos. Na época mais quente do ano, para auxiliar no controle da temperatura interna da casa-de-vegetação, foi acionado um sistema de aspersão de água. Contudo, durante este período houve redução na população do inseto, pois provavelmente a alta umidade relativa interferiu negativamente no desenvolvimento da população.

A ocorrência do predador Delphastus sp. também foi observada durante a

criação de B. tabaci. Este coccinelídeo provavelmente foi levado à casa-de-vegetação junto com outras plantas que se encontravam no mesmo local. Durante este período a população estoque de mosca-branca foi comprometida, devido a alta intensidade de predação de ninfas por este inseto. Essa ocorrência de Delphastus sp. coincidiu com a época de grande densidade populacional de mosca-branca, pois segundo Gerling et al. (2001), a reprodução deste inseto está intimamente ligada a presença de grande quantidade de alimento. As plantas que continham grande número de larvas de Delphastus sp. foram descartadas e os adultos foram parcialmente retirados de forma manual.

Como houve contaminação das plantas com oídio, os sintomas foram observados durante o período de abril a agosto. Este fungo fitopatogênico ocorreu em todas as plantas de soja utilizadas na manutenção da colônia estoque de B. tabaci, impossibilitando a criação do inseto. O crescimento deste fungo ocorreu sobre todas as 
folhas e hastes da planta, formando uma fina camada branco-acinzentada de micélio e esporos pulverulentos. Devido ao grande crescimento do fungo, as folhas de soja caíram após amarelecerem e secarem. Este mesmo problema também ocorreu na criação de $B$. tabaci de Ramos (2001). Segundo Almeida et al. (1997), esta doença em soja ainda é de pouca expressão, embora esteja aumentando em algumas regiões do país. É causada pelo fungo Microsphaera diffusa que também infecta diversas espécies de leguminosas.

Devido a presença do oídio foi intensificada a plantação de amendoim-bravo, erva daninha também hospedeira de B. tabaci para a manutenção da colônia. Contudo, estas plantas também foram infectadas pelo fungo, sendo a criação de mosca-branca severamente afetada durante este período.

\subsection{Toxicidade de agrotóxicos para $B$. bassiana e $M$. anisopliae}

Os resultados do teste de toxicidade, conforme fórmula proposta por Alves et al. (1998a), realizado com 18 produtos fitossanitários e os fungos entomopatogênicos $B$. bassiana (ESALQ 447) e M. anisopliae (ESALQ E9) encontram-se na Tabelas 3, 4 e 5. 
Tabela 3. Diâmetro da colônia e número de conídios, após 7 dias da inoculação e porcentagem do fungo Beauveria bassiana (ESALQ 447) na presença de diferentes agrotóxicos (meio de cultura BDA, $26 \pm 0,5^{\circ} \mathrm{C}, 70 \pm 10 \%$ UR e $12 \mathrm{~h}$ de fotofase).

\begin{tabular}{lccc}
\hline \multicolumn{1}{c}{ Tratamento } & $\begin{array}{c}\text { Diâmetro da Colônia } \\
(\mathbf{m m})\end{array}$ & $\begin{array}{c}\mathbf{N}^{\mathbf{0}} \text { de Conídios } \\
(\mathbf{X ~ X ~ 1 0} \mathbf{)}\end{array}$ & Germinação \\
\hline Testemunha & $30,0 \mathrm{a}$ & $21,52 \mathrm{a}$ & $100,0 \mathrm{a}$ \\
Actara 250 WG & $29,83 \mathrm{ab}$ & $18,02 \mathrm{abcd}$ & $100,0 \mathrm{a}$ \\
Applaud 250 & $20,75 \mathrm{f}$ & $15,70 \mathrm{bcde}$ & $100,0 \mathrm{a}$ \\
Baythroid CE & $18,58 \mathrm{~g}$ & $12,42 \mathrm{ef}$ & $99,75 \mathrm{a}$ \\
Bulldock 125 SC & $30,08 \mathrm{a}$ & $18,50 \mathrm{abc}$ & $100,0 \mathrm{a}$ \\
Calypso & $29,50 \mathrm{abc}$ & $19,20 \mathrm{ab}$ & $100,0 \mathrm{a}$ \\
Cartap BR 500 & $0,00 \mathrm{j}$ & $0,00 \mathrm{~h}$ & $94,50 \mathrm{~b}$ \\
Cercobin 700 PM & $0,00 \mathrm{j}$ & $0,00 \mathrm{~h}$ & $99,50 \mathrm{a}$ \\
Confidor 700 GRDA & $30,33 \mathrm{a}$ & $20,33 \mathrm{a}$ & $100,0 \mathrm{a}$ \\
Cordial 100 & $12,75 \mathrm{~h}$ & $7,45 \mathrm{~g}$ & $98,37 \mathrm{ab}$ \\
Dithane PM & $0,00 \mathrm{j}$ & $0,00 \mathrm{~h}$ & $0,00 \mathrm{~d}$ \\
Kumulus DF & $23,42 \mathrm{e}$ & $14,20 \mathrm{def}$ & $97,75 \mathrm{ab}$ \\
Malathion 1000 CE & $28,17 \mathrm{~cd}$ & $15,15 \mathrm{cde}$ & $99,75 \mathrm{a}$ \\
Meothrin 300 & $8,25 \mathrm{i}$ & $3,48 \mathrm{~h}$ & $53,02 \mathrm{c}$ \\
Oberon 240 SC & $28,58 \mathrm{bcd}$ & $13,67 \mathrm{ef}$ & $98,57 \mathrm{ab}$ \\
Orthene 750 BR & $27,75 \mathrm{~d}$ & $19,88 \mathrm{a}$ & $99,12 \mathrm{a}$ \\
Sumidan 25 CE & $19,50 \mathrm{fg}$ & $10,90 \mathrm{fg}$ & $100,0 \mathrm{a}$ \\
Supracid 400 CE & $0,00 \mathrm{j}$ & $0,00 \mathrm{~h}$ & $0,00 \mathrm{~d}$ \\
Tamaron BR & $30,25 \mathrm{a}$ & $19,63 \mathrm{ab}$ & $100,0 \mathrm{a}$ \\
\hline
\end{tabular}


Tabela 4. Diâmetro da colônia e número de conídios, após 7 dias da inoculação e porcentagem do fungo Metarhizium anisopliae (ESALQ E9) na presença de diferentes agrotóxicos (meio de cultura BDA, $26 \pm 0,5^{\circ} \mathrm{C}, 70 \pm 10 \%$ UR e $12 \mathrm{~h}$ de fotofase).

\begin{tabular}{lccc}
\hline \multicolumn{1}{c}{ Tratamento } & $\begin{array}{c}\text { Diâmetro da Colônia } \\
(\mathbf{m m})\end{array}$ & $\begin{array}{c}\mathbf{N}^{\mathbf{0}} \text { de Conídios } \\
(\mathbf{X ~ x ~ 1 0} \mathbf{)}\end{array}$ & Germinação \\
\hline Testemunha & $22,42 \mathrm{bc}$ & $2,75 \mathrm{def}$ & $100,0 \mathrm{a}$ \\
Actara 250 WG & $21,92 \mathrm{~cd}$ & $3,22 \mathrm{cde}$ & $100,0 \mathrm{a}$ \\
Applaud 250 & $17,00 \mathrm{f}$ & $3,23 \mathrm{cde}$ & $99,25 \mathrm{a}$ \\
Baythroid CE & $17,00 \mathrm{f}$ & $2,32 \mathrm{f}$ & $99,55 \mathrm{abcd}$ \\
Bulldock 125 SC & $23,92 \mathrm{a}$ & $3,70 \mathrm{bc}$ & $96,80 \mathrm{abc}$ \\
Calypso & $23,25 \mathrm{ab}$ & $3,33 \mathrm{bcde}$ & $92,37 \mathrm{bcde}$ \\
Cartap BR 500 & $0,00 \mathrm{j}$ & $0,00 \mathrm{~h}$ & $97,80 \mathrm{abc}$ \\
Cercobin 700 PM & $0,00 \mathrm{j}$ & $0,00 \mathrm{~h}$ & $96,82 \mathrm{abc}$ \\
Confidor 700 GRDA & $22,50 \mathrm{bc}$ & $4,00 \mathrm{bc}$ & $100,0 \mathrm{a}$ \\
Cordial 100 & $8,83 \mathrm{i}$ & $1,13 \mathrm{~g}$ & $97,30 \mathrm{abc}$ \\
Dithane PM & $0,00 \mathrm{j}$ & $0,00 \mathrm{~h}$ & $0,00 \mathrm{f}$ \\
Kumulus DF & $21,17 \mathrm{de}$ & $2,82 \mathrm{def}$ & $88,67 \mathrm{e}$ \\
Malathion 1000 CE & $15,33 \mathrm{~g}$ & $2,67 \mathrm{ef}$ & $91,30 \mathrm{cde}$ \\
Meothrin 300 & $10,25 \mathrm{~h}$ & $1,33 \mathrm{~g}$ & $89,60 \mathrm{de}$ \\
Oberon 240 SC & $21,50 \mathrm{cde}$ & $4,17 \mathrm{~b}$ & $98,52 \mathrm{ab}$ \\
Orthene 750 BR & $20,42 \mathrm{e}$ & $8,07 \mathrm{a}$ & $98,52 \mathrm{ab}$ \\
Sumidan 25 CE & $14,92 \mathrm{~g}$ & $2,25 \mathrm{f}$ & $98,52 \mathrm{ab}$ \\
Supracid 400 CE & $0,00 \mathrm{j}$ & $0,00 \mathrm{~h}$ & $0,00 \mathrm{f}$ \\
Tamaron BR & $20,58 \mathrm{e}$ & $3,58 \mathrm{bcd}$ & $100,0 \mathrm{a}$ \\
\hline
\end{tabular}


Tabela 5. Valores de T e classificação de compatibilidade dos produtos fitossanitários, em relação ao efeito fungitóxico em Beauveria bassiana (ESALQ 447) e Metarhizium anisopliae (ESALQ E9)

\begin{tabular}{|c|c|c|c|c|}
\hline \multirow{2}{*}{ Tratamentos } & \multicolumn{2}{|c|}{ B. bassiana } & \multicolumn{2}{|c|}{ M. anisopliae } \\
\hline & Valor de $\mathbf{T}^{1}$ & Classificação & Valor de $\mathbf{T}^{\mathbf{1}}$ & Classificação \\
\hline Actara $250 \mathrm{WG}$ & 86,84 & Compatível & 110,98 & Compatível \\
\hline Applaud 250 & 72,28 & Compatível & 106,6 & Compatível \\
\hline Baythroid CE & 58,54 & Moder. Tóxico & 80,89 & Compatível \\
\hline Bulldock 125 SC & 88,91 & Compatível & 127,05 & Compatível \\
\hline Calypso & 91,11 & Compatível & 115,09 & Compatível \\
\hline Cartap BR 500 & 0 & Muito Tóxico & 0 & Muito Tóxico \\
\hline Cercobin 700 PM & 0 & Muito Tóxico & 0 & Muito Tóxico \\
\hline Confidor 700 GRDA & 95,74 & Compatível & 134,38 & Compatível \\
\hline Cordial 100 & 37,24 & Tóxico & 39,29 & Tóxico \\
\hline Dithane PM & 0 & Muito Tóxico & 0 & Muito Tóxico \\
\hline Kumulus DF & 68,44 & Compatível & 98,93 & Compatível \\
\hline Malathion $1000 \mathrm{CE}$ & 75,36 & Compatível & 90,8 & Compatível \\
\hline Meothrin 300 & 18,55 & Muito Tóxico & 46,34 & Moder. Tóxico \\
\hline Oberon 240 SC & 70,04 & Compatível & 139,2 & Compatível \\
\hline Orthene 750 BR & 92,58 & Compatível & 249,65 & Compatível \\
\hline Sumidan 25 CE & 53,56 & Moder. Tóxico & 79,02 & Compatível \\
\hline Supracid 400 CE & 0 & Muito Tóxico & 0 & Muito Tóxico \\
\hline Tamaron BR & 93,13 & Compatível & 121,25 & Compatível \\
\hline
\end{tabular}

${ }^{1}$ Fórmula proposta por Alves et al. (1998a).

A metodologia proposta por Alves et al. (1998a) representa uma importante forma de avaliação do efeito tóxico in vitro de produtos químicos aos entomopatógenos, pois neste caso o patógeno é exposto ao máximo à ação dos produtos, o que não ocorre em condições de campo. Por outro lado, quando esses produtos são compatíveis in vitro 
há forte evidência de sua seletividade em condições de campo. Contudo, níveis elevados de toxicidade in vitro não podem ser considerados bons indicadores para o comportamento do produto em condições de campo, embora mostre uma possibilidade de que isto possa ocorrer (Moino Jr. \& Alves, 1998; Alves et al., 2001; Batista Filho et al., 2001; Neves et al., 2001; Loureiro et al., 2002).

Segundo Neves et al. (2001), o crescimento vegetativo do patógeno ocorrerá, ou será inibido somente no interior do inseto. A concentração do produto químico no interior do inseto é provavelmente menor que a utilizada nos testes in vitro. Também, os resultados in vitro representam, de uma maneira mais drástica, o que ocorre com o crescimento vegetativo do patógeno no interior do inseto. Pelas mesmas razões discutidas para o crescimento vegetativo, os dados obtidos in vitro para a produção de conídios (esporulação), não são de fundamental importância. No caso de inseticidas, os insetos que morrem pelo contato com os produtos, provavelmente serão rapidamente colonizados por bactérias saprófitas, eliminando assim, as chances do fungo se desenvolver e conseqüentemente formar seus conídios. No entanto, a esporulação pode ser afetada por pesticidas e o seu efeito inibitório pode afetar as condições epizoóticas da doença ou reduzir a eficiência dos isolados em campo, segundo Gardner \& Storey (1985) .

Atualmente, muitos autores (Anderson \& Roberts, 1983; Malo, 1993; Neves et al., 2001) têm considerado a germinação dos conídios como um dos fatores mais importantes para a compatibilidade de agrotóxicos em condições de campo. A sobrevivência do inóculo de fungos entomopatogênicos, em campo, ocorre por meio dos conídios, sendo que estes quando em contato ou ingeridos pelos insetos, acarretarão na infecção pelo patógeno. 


\subsection{Classificação toxicológica dos agrotóxicos usando os parâmetros crescimento vegetativo, esporulação e germinação de fungos entomopatogênicos}

Para a classificação toxicológica dos agrotóxicos a expressão matemática estabelecida foi:

$$
\mathrm{T}=\frac{47[\mathrm{CV}]+43[\mathrm{ESP}]+10[\mathrm{GER}]}{100}
$$

Algumas exigências são importantes para utilização dessa expressão:

- Número de produtos deve ser no mínimo 5;

- Os valores de CV, ESP e GER devem ser previamente corrigidos em relação às respectivas testemunhas;

- Não utilizar casas decimais para obtenção do Valor de T;

- Utilizar a análise de agrupamento ao invés da análise de variância.

Os resultados obtidos encontram-se nas Tabelas 6 e 7, com as respectivas análises de agrupamento na Figuras 1 e 2. 


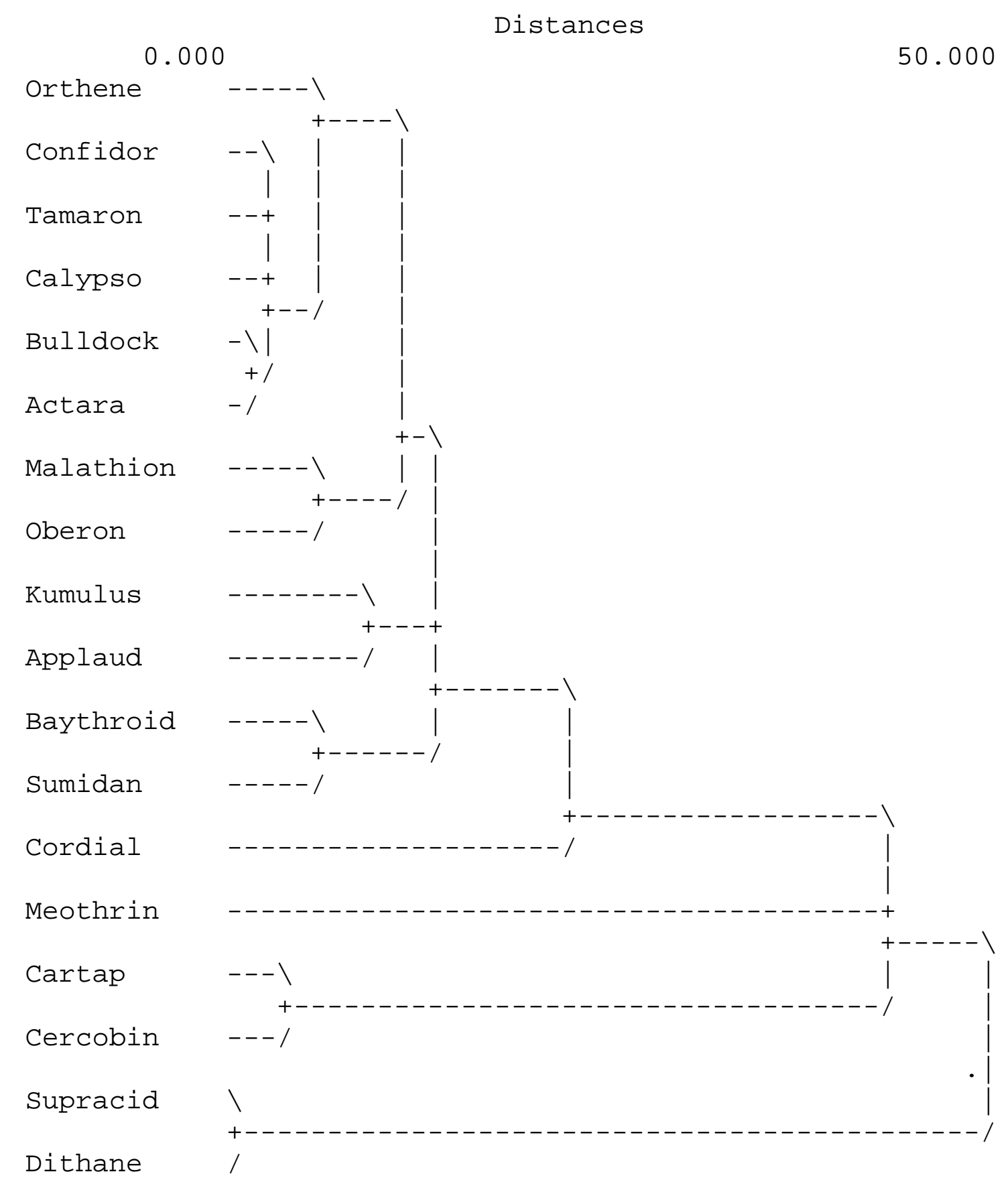

Figura 1 - Análise de Agrupamento (Cluster) do crescimento vegetativo (CV), esporulação (ESP) e germinação (GER) de Beauveria bassiana (ESALQ 447) 


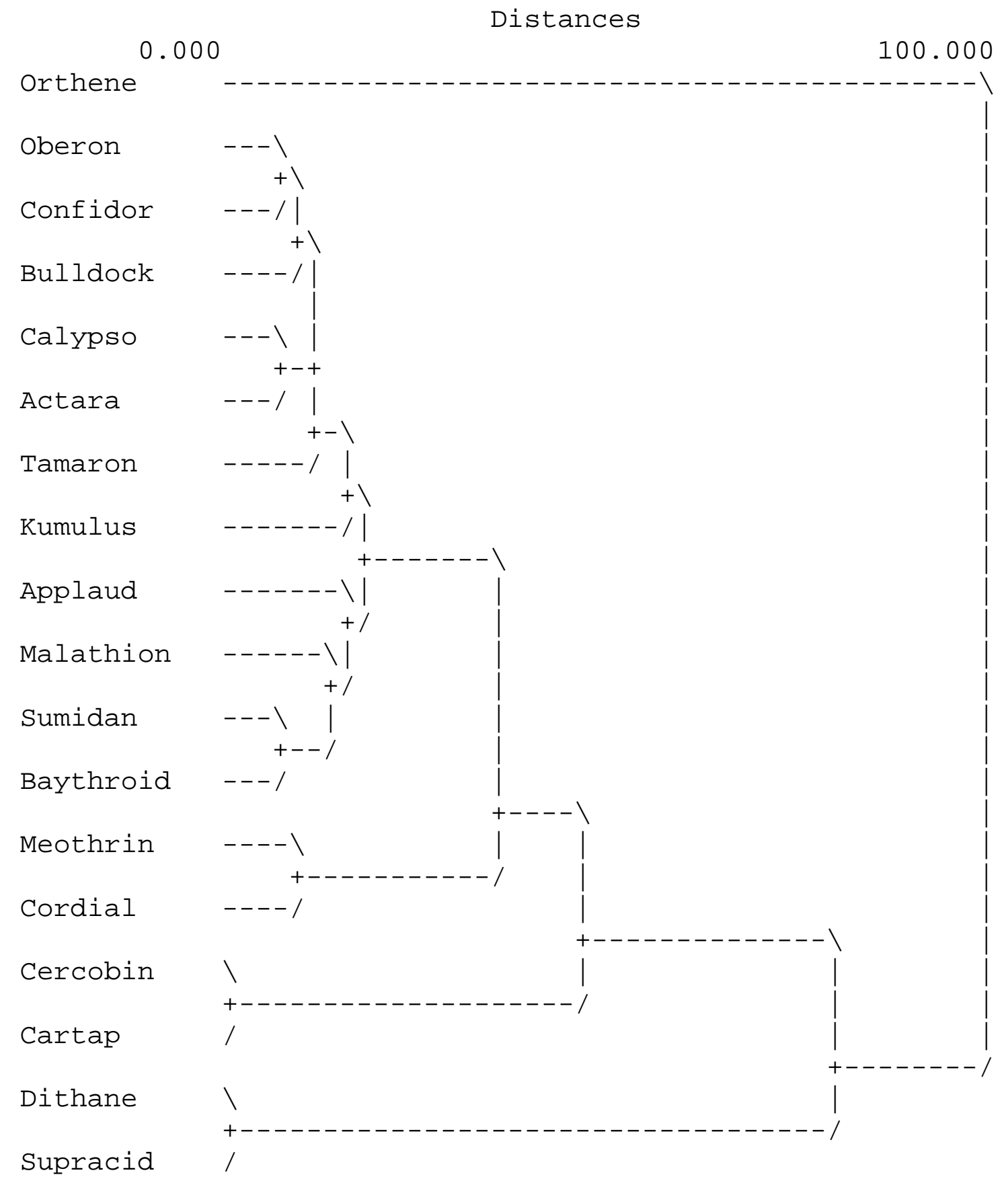

Figura 2 - Análise de Agrupamento (Cluster) do crescimento vegetativo (CV), esporulação (ESP) e germinação (GER) de Metarhizium anisopliae (ESALQ E9) 
Tabela 6. Valores de crescimento vegetativo (CV), esporulação (ESP) e germinação (GER) corrigidos pela testemunha, valor de T e respectiva classificação para Beauveria bassiana (ESALQ 447)

\begin{tabular}{lccccc}
\hline \multicolumn{1}{c}{ Tratamentos } & $\begin{array}{c}\text { CV } \\
(\mathbf{m m})\end{array}$ & $\begin{array}{c}\text { ESP } \\
(\mathbf{n ~ x ~ 1 0} \mathbf{7})\end{array}$ & $\begin{array}{c}\text { GER } \\
(\mathbf{\%})\end{array}$ & Valor T & Classificação \\
\hline Actara 250 WG & 99,33 & 83,72 & 100,00 & 93 & Compatível \\
Applaud 250 & 69,33 & 73,02 & 100,00 & 74 & Tóxico \\
Baythroid CE & 62,00 & 57,67 & 99,75 & 64 & Tóxico \\
Bulldock 125 SC & 100,33 & 86,05 & 100,00 & 94 & Compatível \\
Calypso & 98,33 & 89,30 & 100,00 & 95 & Compatível \\
Cartap BR 500 & 0,00 & 0,00 & 94,50 & 9 & Muito Tóxico \\
Cercobin 700 PM & 0,00 & 0,00 & 99,50 & 10 & Muito Tóxico \\
Confidor 700 GRDA & 101,00 & 94,42 & 100,00 & 98 & Compatível \\
Cordial 100 & 42,66 & 35,88 & 98,37 & 45 & Tóxico \\
Dithane PM & 0,00 & 0,00 & 0,00 & 0 & Muito Tóxico \\
Kumulus DF & 78,00 & 66,05 & 97,75 & 75 & Tóxico \\
Malathion 1000 CE & 94,00 & 70,70 & 99,75 & 85 & Compatível \\
Meothrin 300 & 27,66 & 16,28 & 53,02 & 25 & Muito Tóxico \\
Oberon 240 SC & 95,33 & 63,72 & 98,57 & 82 & Compatível \\
Orthene 750 BR & 92,66 & 92,56 & 99,12 & 93 & Compatível \\
Sumidan 25 CE & 65,00 & 50,70 & 100,00 & 62 & Tóxico \\
Supracid 400 CE & 0,00 & 0,00 & 0,00 & 0 & Muito Tóxico \\
Tamaron BR & 101,00 & 91,16 & 100,00 & 97 & Compatível \\
\hline Média = 61,18 & Desvio Padrão = 36,39 Intervalo de Confiança (IC) = (44; 78) \\
& & & & &
\end{tabular}


Tabela 7. Valores de crescimento vegetativo (CV), esporulação (ESP) e germinação (GER) corrigidos pela testemunha, valor de T e respectiva classificação para Metarhizium anisopliae (ESALQ E9)

\begin{tabular}{lccccc}
\hline \multicolumn{1}{c}{ Tratamentos } & $\begin{array}{c}\text { CV } \\
(\mathbf{m m})\end{array}$ & $\begin{array}{c}\text { ESP } \\
\left(\mathbf{n ~ x ~ 1 0} \mathbf{7}^{\mathbf{c}}\right.\end{array}$ & $\begin{array}{c}\text { GER } \\
\mathbf{( \% )}\end{array}$ & Valor T & Classificação \\
\hline Actara 250 WG & 97,77 & 114,28 & 100,00 & 105 & Compatível \\
Applaud 250 & 75,89 & 114,28 & 99,25 & 95 & Tóxico \\
Baythroid CE & 75,89 & 82,14 & 95,55 & 80 & Tóxico \\
Bulldock 125 SC & 106,70 & 132,14 & 96,80 & 117 & Compatível \\
Calypso & 104,02 & 117,86 & 92,37 & 109 & Compatível \\
Cartap BR 500 & 0,00 & 0,00 & 97,80 & 10 & Muito Tóxico \\
Cercobin 700 PM & 0,00 & 0,00 & 96,82 & 10 & Muito Tóxico \\
Confidor 700 GRDA & 100,45 & 142,86 & 100,00 & 119 & Compatível \\
Cordial 100 & 39,29 & 39,29 & 97,30 & 45 & Muito Tóxico \\
Dithane PM & 0,00 & 0,00 & 0,00 & 0 & Muito Tóxico \\
Kumulus DF & 94,64 & 100,00 & 88,67 & 96 & Tóxico \\
Malathion 1000 CE & 68,30 & 96,43 & 91,30 & 83 & Tóxico \\
Meothrin 300 & 45,98 & 46,43 & 89,59 & 50 & Muito Tóxico \\
Oberon 240 SC & 95,98 & 150,00 & 98,52 & 119 & Compatível \\
Orthene 750 BR & 91,07 & 289,29 & 98,52 & 177 & Compatível \\
Sumidan 25 CE & 66,52 & 82,14 & 98,52 & 76 & Tóxico \\
Supracid 400 CE & 0,00 & 0,00 & 0,00 & 0 & Muito Tóxico \\
Tamaron BR & 91,96 & 128,57 & 100,00 & 108 & Compatível \\
\hline Média = 77,78 & Desvio Padrão = 49,27 Intervalo de Confiança (IC) = (55; 100)
\end{tabular}

Como pode ser observado nas Figuras 1 e 2, os produtos fitossanitários podem ser agrupados em 2 grandes grupos, através da Análise de Agrupamento (Cluster), quanto ao efeito tóxico aos fungos B. bassiana (ESALQ 447) e M. anisopliae (ESALQ E9). No primeiro grupo estão presentes os produtos compatíveis e/ ou de moderada 
toxicidade, sendo estes: Actara 250 WG (thiamethoxan), Applaud 250 (buprofezin), Baythroid CE (cyfluthrin), Bulldock 125 SC (betacyfluthrin), Calypso (triacloprid), Confidor 700 GRDA (imidacloprid), Kumulus DF (enxofre), Malathion 1000 CE (malation), Oberon 240 SC (spiromesifen), Orthene 750 BR (acefato), Sumidan 25 CE (esfenvalerate) e Tamaron BR (metamidophos).

O segundo grupo de produtos é composto pelos agrotóxicos que apresentaram uma maior toxicidade aos entomopatógenos utilizados nos testes, sendo estes: Cartap BR 500 (cartap), Cercobin 700 PM (tiofanato-metílico), Cordial 100 (pyriproxyfen), Dithane PM (mancozeb), Meothrin 300 (fenpropathrin) e Supracid 400 CE (methidathion).

No entanto, quando foi calculado o valor de $\mathrm{T}$ para esses produtos, quando submetidos a expressão matemática para posterior classificação, pôde-se observar uma separação mais rígida quanto à toxicidade dos mesmos as formulações.

Os produtos Dithane PM (mancozeb) e Supracid 400 CE (methidathion) inibiram totalmente os três parâmetros avaliados (CV, ESP e GER), nos dois fungos estudados. Assim, o valor de T, em ambas as expressões foi igual a zero, sendo considerado muito tóxico para os patógenos. Segundo Griffith et al. (1992) citado por Loureiro et al. (2002), mancozeb é um ditiocarbamato com largo espectro e não específico no modo de ação contra fungos fitopatogênicos, afetando assim, o crescimento dos Hyphomycetes de maneira geral.

O crescimento vegetativo (CV) e a esporulação (ESP) de B. bassiana (ESALQ 447) e M. anisopliae (ESALQ E9), também foram totalmente inibidos pela ação dos agrotóxicos Cartap BR 500 (cartap) e Cercobin 700 PM (tiofanato-metílico). Contudo, a germinação dos fungos foi alta (94 a 99,5 \%), em avaliação feita após 24 horas, de acordo com metodologia descrita no item 3.2. Como pode ser observado nas Tabelas (3, 4, 5, 6 e 7), os valor de T dos produtos Cartap BR 500 e Cercobin 700 PM aumentaram com a mudança do cálculo utilizando-se a nova expressão matemática, embora suas classificações tenham sido mantidas como muito tóxicos para os fungos B. bassiana e M. anisopliae. 
Em teste realizado por Pachamuthu et al. (1999), o crescimento vegetativo e a esporulação de $M$. anisopliae isolado ESC-1 foi mais sensível aos inseticidas do que a germinação deste fungo. Não houve diferença significativa na germinação dos conídios de $M$. anisopliae isolado ESC-1 no meio de cultura com diferentes concentrações de chlorpyrifos, propetamphos e cyfluthrin. Uma alta germinação foi observada após 12 horas de incubação em meio de cultura com inseticidas. Esta germinação pode ter sido influenciada pela prévia exposição dos conídios ao meio SDAY (Sabouraud, dextrose, ágar e levedura), resultando numa reserva de nutrientes (carboidratos, lipídios e aminoácidos) suficiente dar inicio ao processo de desenvolvimento do tubo germinativo, quando este foi colocado em um substrato sólido contendo nutrientes exógenos.

A maioria dos pesticidas testados por Moorhouse et al. (1992) citado por Pachamuthu et al. (1999), também não afetou a germinação dos conídios, com exceção do zineb e chlorothalonil. No entanto, o crescimento da colônia foi afetado por todos os pesticidas, com exceção do propamocarb. Assim, somente a germinação não poderia ser utilizada como um indicador para prever a compatibilidade de agrotóxicos para entomopatógenos. Mas a alta germinação de um isolado mostra seu potencial como agente efetivo sob ótimas condições de temperatura, umidade relativa e presença de fontes de nutrientes exógenos.

Tamai et al. (2002) também avaliou a toxicidade do inseticida/ fungicida Cartap BR 500 e dos fungicidas Cercobin 700 PM e Dithane PM e resultados semelhantes foram obtidos. Os três produtos foram classificados como muito tóxico ao fungo $B$. bassiana (ESALQ PL63). A expressiva toxicidade dos fungicidas é um dos fatores que mais prejudicam a ação dos fungos entomopatogênicos. A adoção conjunta de medidas de controle que minimizem a presença de fitopatógenos na cultura e, conseqüentemente, a necessidade de aplicações de fungicidas para seu controle, é um procedimento importante que deve ser adotado para reduzir o efeito de fungicidas sobre os entomopatógenos. Outra possibilidade, é a aplicação do fungicida somente nos focos da doença, além de pulverizar o fungicida com intervalos de tempo suficiente para não coincidir com as fases mais susceptíveis da interação entomopatógeno-hospedeiro. No 
entanto, isso depende do comportamento de cada fitopatógeno e do tipo de dano que o mesmo pode causar.

A utilização de fungicidas compatíveis aos fungos entomopatogênicos é uma outra alternativa a ser utilizada. O fungicida Kumulus DF (enxofre) foi considerado compatível a B. bassiana e M. anisopliae de acordo com a expressão matemática de Alves et al. (1998a), resultado este também encontrado por Tamai et al. (2002). No entanto, com a alteração proposta, este produto passou de compatível para tóxico à ambos os fungos.

O produto Meothrin 300 (fenpropathrin) foi classificado como muito tóxico para B. bassiana em ambas as expressões matemáticas (Tabelas 3 e 4), pois afetou consideravelmente os três parâmetros avaliados. No entanto, houve uma variação na sua classificação para o fungo $M$. anisopliae. De acordo com a expressão proposta inicialmente por Alves et al. (1998a) este produto foi considerado como moderadamente tóxico (Tabela 3), reduzindo em cerca de $50 \%$ o crescimento vegetativo e a esporulação de $M$. anisopliae, embora a germinação tenha sido somente afetada em cerca de $11 \%$. Com a aplicação da nova expressão matemática, o produto Meothrin 300 passou a ser, também classificado como muito tóxico ao fungo M. anisopliae.

Em trabalho de Oliveira et al. (2003), o produto Meothrin 300 (fenpropathrin) em concentração de campo, causou uma inibição de $46 \%$ da germinação do fungo $B$. bassiana (isolado CG 425), muito semelhante ao ocorrido neste trabalho. Contudo, o crescimento vegetativo (CV) e a esporulação (ESP) não foram observados por Oliveira et al. (2003), para este isolado de B. bassiana.

O crescimento vegetativo (CV) e a esporulação (ESP) de B. bassiana e $M$. anisopliae foram reduzidos em cerca de 57 a 65\% pela ação do produto Cordial 100 (pyriproxyfen). Mas a germinação destes fungos, praticamente não foi afetada pelo produto. Assim, o Cordial 100 foi classificado como tóxico para B. bassiana em ambas expressões utilizadas (Tabelas 3 e 4). Já para o fungo M. anisopliae, que inicialmente o Cordial 100 tinha sido classificado como tóxico, como a nova expressão matemática, passou a considerado muito tóxico a este patógeno. 
Uma redução de 40 a 50\% no crescimento vegetativo (CV) e na esporulação (ESP) de B. bassiana ocorreu pela ação dos produtos Baythroid CE (cyfluthrin) e Sumidan 25 CE (esfenvalerate). Em trabalho de Oliveira et al. (2003), o produto Baythroid CE reduziu em 48,16\% o crescimento vegetativo de B. bassiana (isolado CG 425), mas a esporulação manteve-se alta, assemelhando-se a testemunha, sendo este produto, em concentração de campo, classificado como compatível ao fungo testado.

$\mathrm{O}$ crescimento vegetativo (CV) de M. anisopliae também foi reduzido em 34,5\% pelo produto Sumidan 25 CE. Contudo, o Baythroid CE praticamente não afetou o crescimento vegetativo (CV) e a esporulação (ESP) de M. anisopliae. A germinação (GER) de B. bassiana e M. anisopliae ficaram acima de $95 \%$ sob a ação de ambos os produtos. Assim, de acordo com a expressão matemática de Alves et al. (1998a), os produtos Baythroid CE e Sumidan 25 CE foram classificados como moderadamente tóxicos a B. bassiana e compatíveis com M. anisopliae. Mas com a mudança na expressão matemática, Baythroid CE e Sumidan 25 CE passaram a ser classificados como tóxicos aos dois fungos estudados.

Os produtos Applaud 250 (buprofezin) e Malathion 1000 CE (malation) foram classificados como compatíveis aos fungos entomopatogênicos B. bassiana e $M$. anisopliae, conforme a expressão matemática anteriormente utilizada (Tabela 5). Com a alteração proposta estes produtos passaram e ser classificados como tóxicos (Tabelas 6 e 7) aos fungos estudados. Este fato pode ter ocorrido devido aos produtos terem reduzidos cerca de $30 \%$ ao crescimento vegetativo (CV) e a esporulação (ESP) destes fungos. Contudo, o Malathion 1000 CE manteve-se a sua classificação como compatível ao fungo B. bassiana.

Em testes realizados por Tamai et al. (2002), o Applaud 250 foi muito tóxico para B. bassiana isolado (ESALQ PL63). A variabilidade genética natural entre isolados de uma mesma espécie de fungo entomopatogênico é bastante conhecida e amplamente relatada na literatura para diversos parâmetros biológicos, inclusive para a sensibilidade a produtos químicos sintéticos (Alves, 1986; Paccola-Meireles \& Azevedo, 1990; Alves et al. 1998c). Todorova et al. (1998) têm utilizado esta característica para, em parte, 
explicar as diferentes respostas de fungos entomopatogênicos na presença de um mesmo produto químico.

Dos 18 produtos testados 8 foram classificados como compatíveis ao fungo $B$. bassiana em ambas as expressões utilizadas, são eles: Actara 250 WG (thiamethoxan), Bulldock 125 SC (betacyfluthrin), Calypso (triacloprid), Confidor 700 GRDA (imidacloprid), Malathion 1000 CE (malation), Oberon 240 SC (spiromesifen), Orthene 750 BR (acefato) e Tamaron BR (metamidophos). O mesmo ocorreu com o fungo $M$. anisopliae com exceção somente do produto Malathion 1000 CE (Tabelas 3, 4 e 5).

Alguns produtos que foram classificados, de acordo com a expressão matemática de Alves et al. (1998a), como compatíveis com os fungos testados tiveram valores de "T" (Tabela 3) muito próximos ou superiores a 100. Este fato ocorreu somente no teste com M. anisopliae, com os produtos: Actara 250 WG, Applaud 250, Bulldock 125 SC, Calypso, Confidor 700 GRDA, Kumulus DF, Oberon 240 SC, Orthene 750 BR e Tamaron BR. De acordo com Tamai et al. (2002), produtos com valores próximos a 100 apresentam comportamento muito semelhante à testemunha para os parâmetros avaliados. Assim, a presença destes produtos no meio de cultura representou um estímulo à produção de conídios (ESP), mas nem sempre para o crescimento da colônia (CV) destes fungos.

O crescimento vegetativo (CV) de M. anisopliae na presença, principalmente, dos produtos Confidor 700 GRDA e Orthene 750 BR foi igual ou inferior a testemunha. Contudo, o número de conídios (ESP) do fungo foi muito superior à testemunha, havendo um aumento de 45,5 \% e 193,5\%, na presença dos produtos Confidor 700 GRDA e Orthene $750 \mathrm{BR}$, respectivamente. Em testes de toxicidade realizados por Neves et al. (2001) com imidacloprid para B. bassiana (ESALQ 447) e M. anisopliae (ESALQ E9), resultados semelhantes foram obtidos. Este aumento na produção de conídios de M. anisopliae na presença destes produtos no meio de cultura pode ter ocorrido devido aos seguintes motivos: 1) metabolização dos inseticidas e uso dos metabólitos, liberados aos fungos, como nutrientes secundários; e 2) em um meio tóxico, os fungos podem realizar uma reprodução forçada, aumentando o número de conídios. Outra possibilidade seria a de que estas substâncias presentes nas formulações dos 
inseticidas, poderiam ser utilizadas diretamente como nutrientes, aumentando assim, o crescimento vegetativo e a produção de conídios do patógeno (Moino Jr. \& Alves, 1998; Loureiro et al., 2002; Tamai et al., 2002).

A toxicidade dos produtos Actara 250 WG (thiamethoxan), Confidor 700 GRDA (imidacloprid) e Orthene 750 BR (acefato) também foram testados por Batista Filho et al. (2001), para os fungos B. bassiana isolado (CB 66) e M. anisopliae (SLP 358). Neste trabalho o produto Actara 250 WG também foi compatível com ambos os fungos testados. O mesmo não ocorreu com os demais produtos, com exceção do Orthene 750 BR que foi compatível com B. bassiana, o Confidor 700 GRDA foi moderadamente tóxico ao mesmo fungo. Para M. anisopliae, Orthene 750 BR e Confidor 700 GRDA foram classificados como moderadamente tóxico na máxima concentração e incompatível na mínima concentração utilizada. O crescimento vegetativo e esporulação de M. anisopliae não foram afetados pelo Actara 250 WG, Confidor 700 GRDA e Orthene 750 BR utilizados na concentração máxima. Contudo na concentração mínima, Confidor 700 GRDA e Orthene 750 BR reduziram significantemente a produção de conídios, apesar de não ter afetado o diâmetro das colônias. Isto demonstra a ausência de correlação entre estes dois parâmetros.

De acordo com os resultados obtidos nas Tabelas 3, 4, 5, 6 e 7 esta nova expressão matemática, avalia em conjunto, os três parâmetros, crescimento vegetativo, esporulação e germinação. Considerando os valores de $\mathrm{T}$, determina-se o intervalo de segurança para cada espécie de fungo, determinando-se a toxicidade de cada formulação para a espécie de patógeno testada.

\subsection{Efeito de subdoses de spiromesifen sobre ninfas de B. tabaci}

Somente o Oberon 240 SC (spiromesifen) foi utilizado nos testes com B. tabaci biótipo B, pois além de sua compatibilidade com estes entomopatógenos, também possui baixa toxicidade (Classe IV) (Wiesbrook, 2003). Este é um produto novo que ainda será lançado no mercado brasileiro para o controle de ácaros e moscas-brancas. Assim, populações deste inseto ainda não tiveram contato com este tipo de produto, o que não 
ocorre com os demais produtos testados, e problemas com o desenvolvimento de resistência poderão ser evitados. Em trabalhos realizados por Schuster et al. (2003) e Liu (2004), o spiromesifen se mostrou muito eficiente no controle de ninfas de B. tabaci, quando comparado com os demais produtos testados.

Os resultados obtidos no teste realizado para avaliar o efeito de subdoses de spiromesifen sobre ninfas de $3^{\circ}$ ínstar de B. tabaci estão apresentados na Tabela 8 e na Figura 3.

Como pode ser observado na Tabela 8, a média de mortalidade foi diretamente proporcional a concentração utilizada do inseticida químico nos tratamentos. Não se observou diferença estatística entre o tratamento com a dose comercialmente recomendada e no tratamento com $75 \%$ da dose. Este fato pode ter ocorrido em função da diminuição da concentração do produto na calda de aplicação (25\%) ter sido insuficiente para causar grandes diferenças na mortalidade do inseto.

Tabela 8. Porcentagem de mortalidade de ninfas de $3^{\circ}$ ínstar de Bemisia tabaci tratadas com subdoses de spiromesifen

\begin{tabular}{lc}
\hline \multicolumn{1}{c}{ Tratamentos } & \% de Mortalidade de ninfas \\
\hline Testemunha & $12,8 \mathrm{~d}$ \\
Dose Recomendada & $79,9 \mathrm{a}$ \\
$75 \%$ da Dose Recomendada & $75,1 \mathrm{a}$ \\
$50 \%$ da Dose Recomendada & $53,5 \mathrm{~b}$ \\
$25 \%$ da Dose Recomendada & $35,3 \mathrm{c}$ \\
\hline Médias seguidas por letras distintas em mesma coluna diferem entre si ao \\
nível de $5 \%(\mathrm{p}<0.05)$.
\end{tabular}




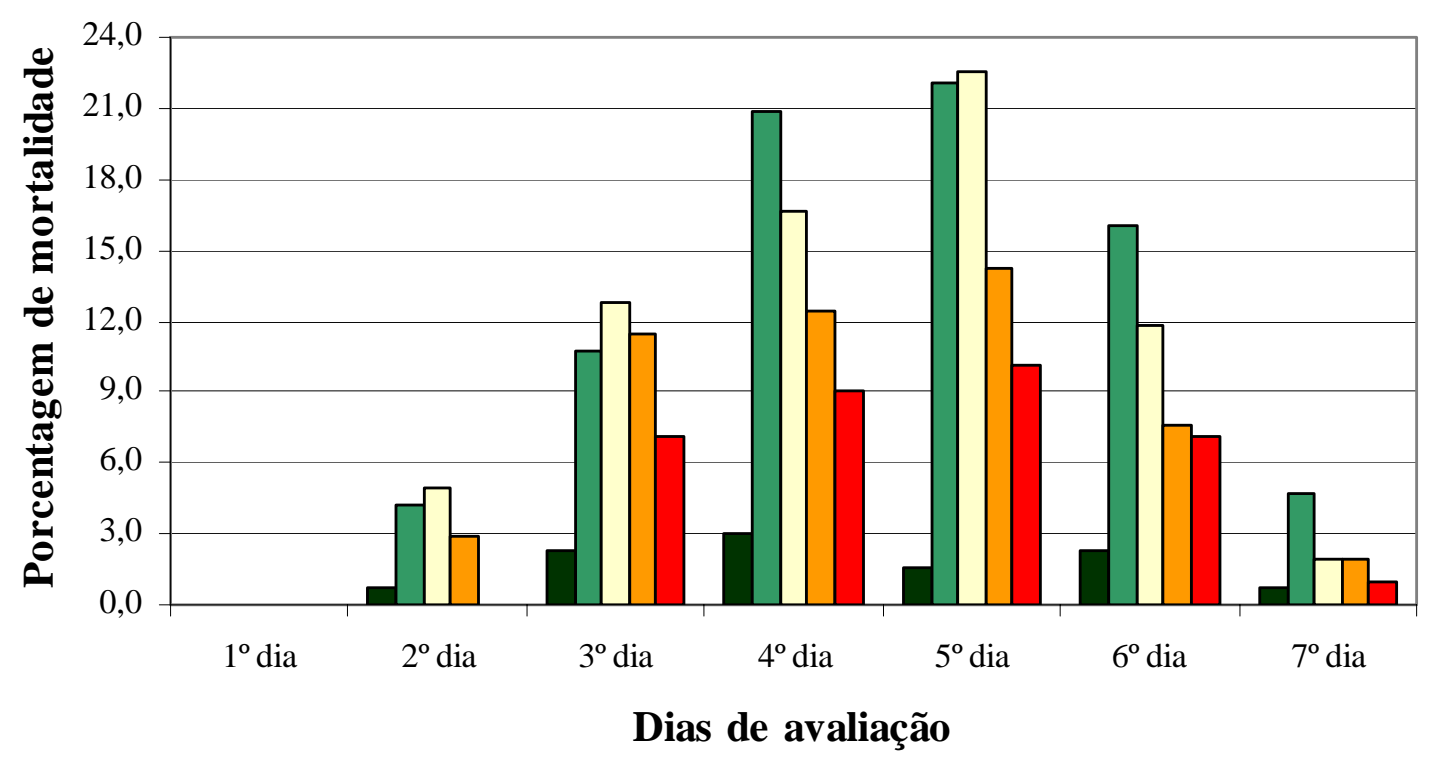

Testemunha $\square$ Dose recomendada $\square 75 \%$ da dose $\square 50 \%$ da dose $\square 25 \%$ da dose

Figura 3 - Porcentagem de mortalidade diária de ninfas de $3^{\circ}$ ínstar de Bemisia tabaci tratadas spiromesifen

As ninfas do segundo ao quarto ínstar são imóveis e assim houve uma grande dificuldade na avaliação da mortalidade pela ação do produto químico. Dessa maneira, foram consideradas mortas somente ninfas que tiveram sua coloração alterada, de amarelo-pálido para amarelo-escuro ou marrom claro. Também foram consideradas mortas ninfas que apresentavam um aspecto ressecado e as ninfas que não conseguiram mudar de ínstar.

O pico de mortalidade no tratamento com a formulação Oberon 240 SC (spiromesifen) foi observado no quinto dia de avaliação (Figura 1). Isto ocorreu provavelmente, pela dificuldade de avaliação, anteriormente citada, sendo assim necessário um período mais longo para a confirmação da mortalidade. No primeiro dia não se verificou a mortalidade de ninfas e no segundo dia somente no tratamento com $25 \%$ da dose recomendada não se constatou mortalidade.

Talvez, maior mortalidade poderia ser observada, se as avaliações fossem prorrogadas mais alguns dias, até o período de emergência dos adultos. Mas isso não foi 
possível, pois as folhas de soja utilizadas não resistiram por muito tempo, ocorrendo uma murcha e posterior ressecamento, impedindo a continuidade das avaliações.

\subsection{Efeito de B. bassiana e M. anisopliae e spiromesifen sobre larvas de Delphastus} sp.

A mortalidade observada de larvas de Delphastus sp. durante as avaliações foi muito baixa, não sendo possível a análise estatística dos dados. Durante o período avaliado ocorreu a morte de seis larvas, sendo duas pertencentes a testemunha, duas ao tratamento com Boveril ${ }^{\circledR}$ PM e duas no tratamento com Boveril ${ }^{\circledR} \mathrm{PM}+\mathrm{o}$ inseticida spiromesifen. Esta mortalidade pode ter sido, provavelmente, ocasionada pela manipulação dos insetos durante sua transferência sobre as folhas de soja.

Durante os dias de avaliação todas as larvas utilizadas no bioensaio apresentavam grande mobilidade sobre as folhas. Também não foram observadas mudanças no comportamento alimentar destes insetos durante este período.

Em estudo de toxicidade realizado por Torre et al. (2003) com larvas, pupas e adultos de Delphastus pusillus, a mortalidade observada em folhas tratadas com thiamethoxam foi de 70 a 100\%, enquanto àqueles liberados em folhas tratadas com pymetrozine a mortalidade ficou entre 0 e $20 \%$.

A ação de buprofezin e pyriproxyfen sobre adultos de Delphastus catalinae foi observada por Liu e Stansly (2004), utilizando-se ovos de B. tabaci tratados com ambos produtos. O buprofezin foi pouco compatível com D. catalinae, causando um decréscimo na longevidade, aumento no período de pré-oviposição e um efeito devastador na fecundidade e fertilidade deste predador. Além disso, este efeito não foi reversível, quando os mesmos adultos foram então alimentados com ovos não tratados. No entanto, o efeito do pyriproxyfen em adultos de $D$. catalinae foi de altamente reversível e ainda pôde ser facilmente manejado.

Em testes de compatibilidade com BotaniGard (produto comercial a base de $B$. bassiana, Mycotech) sobre adultos de quatro espécies de coccinelídeos, mostrou que este não afetou Hippodamia convergens e Harmonia axyridis. No entanto a 
sobrevivência após 72 horas de Cryptolaemus montrouzieri decresceu drasticamente, enquanto que para Coleomegilla maculata a sobrevivência foi afetada após 8 horas em duas das três repetições utilizadas (Smith \& Krischik, 2000).

Os resultados obtidos com larvas de Delphastus sp., importante inimigo natural de mosca-branca, demonstra a baixa toxicidade destes produtos sobre esta fase do desenvolvimento do inseto. A busca e utilização de produtos menos tóxicos e mais seletivos a inimigos naturais são algumas das estratégias para o manejo de pragas, evitando assim, o uso excessivo de inseticidas.

Para realmente comprovar a baixa ação destes produtos sobre este inseto, outros testes seriam necessários, como testes para avaliar sua ação sobre diferentes fases do ciclo evolutivo de Delphastus sp., sobre sua taxa de oviposição, fecundidade, longevidade entre outros parâmetros.

\subsection{Efeito da associação de spiromesifen e fungos entomopatogênicos sobre ninfas de B. tabaci em tomateiros sob condição de cultivo protegido}

Para avaliar o número de adultos presentes nas plantas de tomate nos diferentes tratamentos antes do início das pulverizações, três avaliações foram realizadas. Assim, foi obtida uma média destas três avaliações sendo determinado o número de adultos de mosca-branca presentes nas plantas de cada tratamento antes do inicio das pulverizações. Estes valores estão representados nas Figuras 4, 5 e 6. 


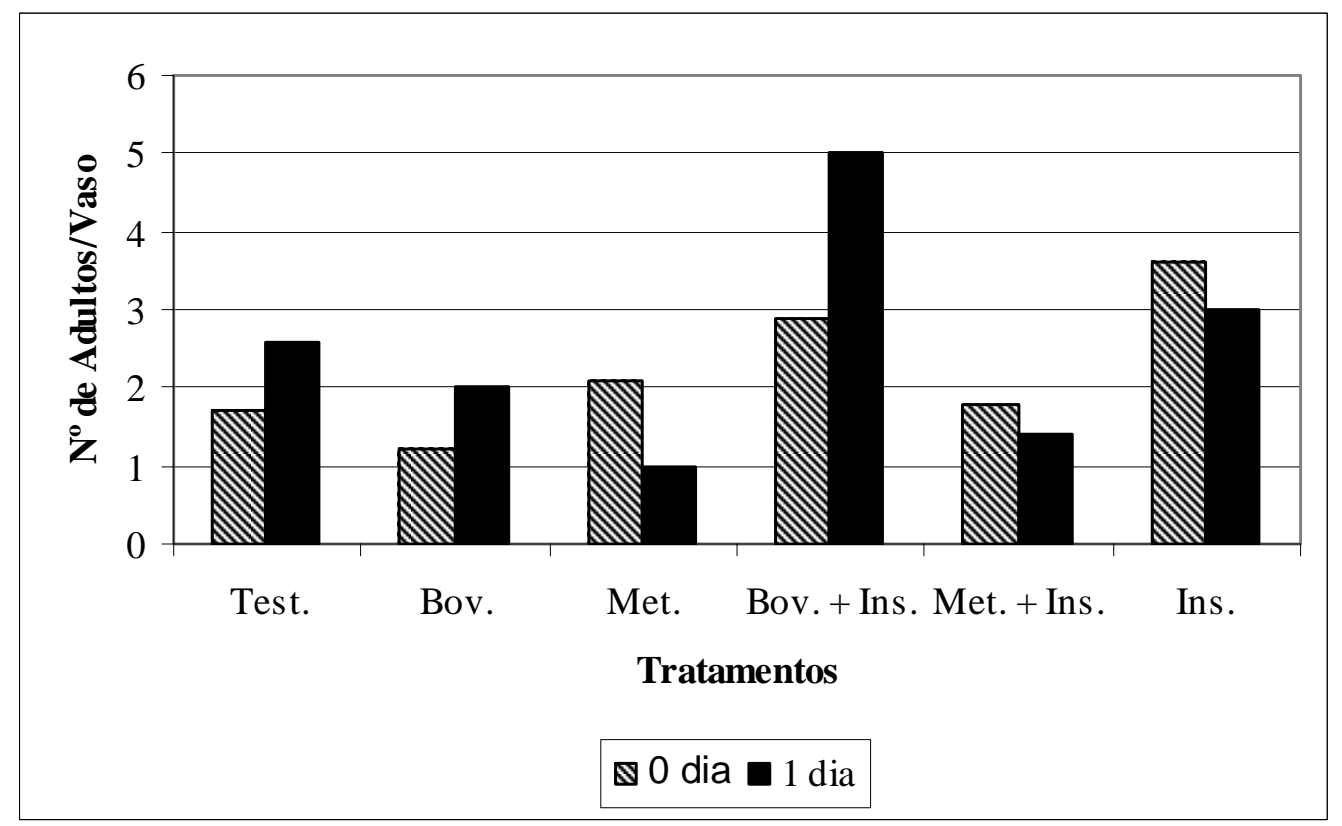

Figura 4 - Número de adultos de Bemisia tabaci antes do início das pulverizações (0 dia) e após um dia da realização da primeira pulverização

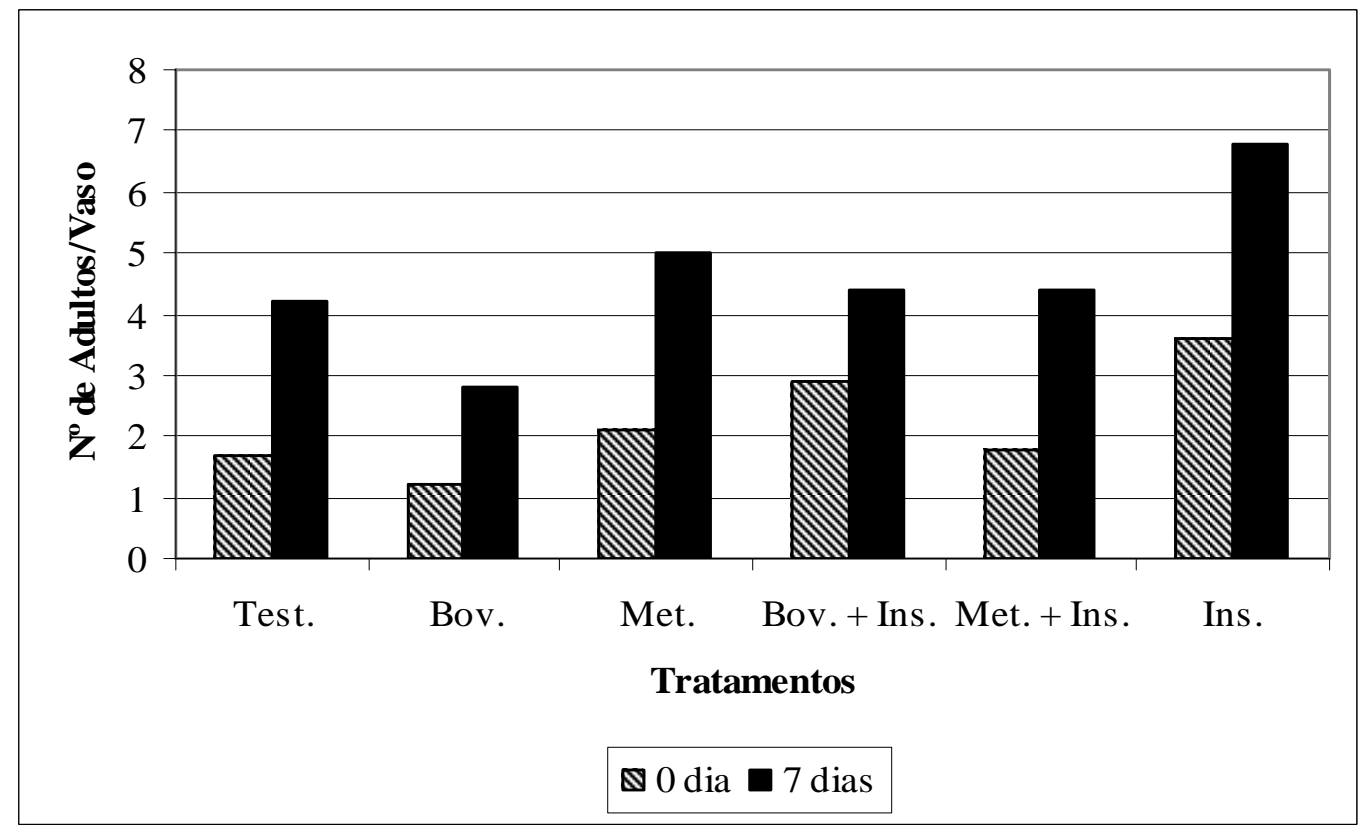

Figura 5 - Número de adultos de Bemisia tabaci antes do início das pulverizações (0 dia) e após sete dias da realização da primeira pulverização, ou seja, após 3 pulverizações 


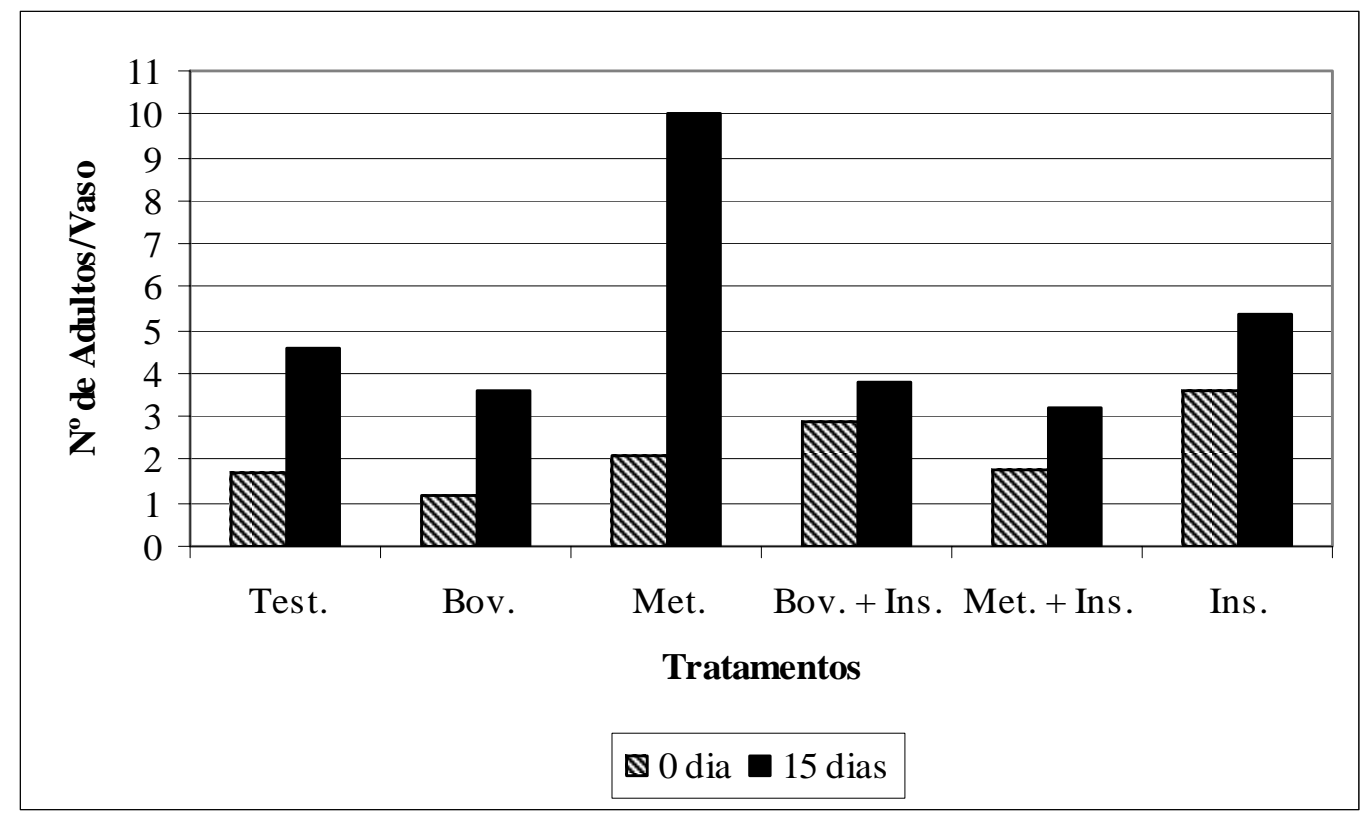

Figura 6 - Número de adultos de Bemisia tabaci antes do início das pulverizações (0 dia) e após quinze dias da realização da primeira pulverização, ou seja, após 6 pulverizações

Até a idade de 50 dias foram realizadas três pulverizações por semana, devido a maior suscetibilidade de plantas jovens de tomate ao ataque de moscas-brancas. Após este período, com plantas de idade superior a 50 dias, as pulverizações passaram a ser semanais. Como pode ser observado nas Figuras 4, 5 e 6, o número de adultos no tratamento com Boveril ${ }^{\circledR}$ PM cresceu ao longo dos dias avaliados, demonstrando que o produto provavelmente não afetou a presença de adultos nas plantas de tomate. $\mathrm{O}$ mesmo ocorreu com a testemunha como era esperado.

No tratamento com Metarril PM houve um decréscimo no número de adultos após a primeira aplicação (Figura 4). No entanto, um grande aumento no número deste inseto foi observado durante as duas avaliações seguintes (7 e 15 dias), diferindo dos demais tratamentos.

Nos tratamentos em que o inseticida Oberon 240 SC (spiromesifen) foi aplicado sozinho ou associado ao Boveril ${ }^{\circledR}$ PM e Metarril PM, pouca diferença foi observada na 
população de B. tabaci nos diferentes dias avaliados e a variação no número de insetos nos três tratamentos também foi considerada baixa.

A partir da quinta avaliação, que passaram a ser realizadas quinzenalmente, a determinação do número de adultos por vaso ficou impossibilitada, devido ao grande aumento no porte das plantas,. Assim, as avaliações seguintes foram realizadas contando o número de ninfas vivas e mortas nas folhas da planta, com o auxílio de um estereoscópio.

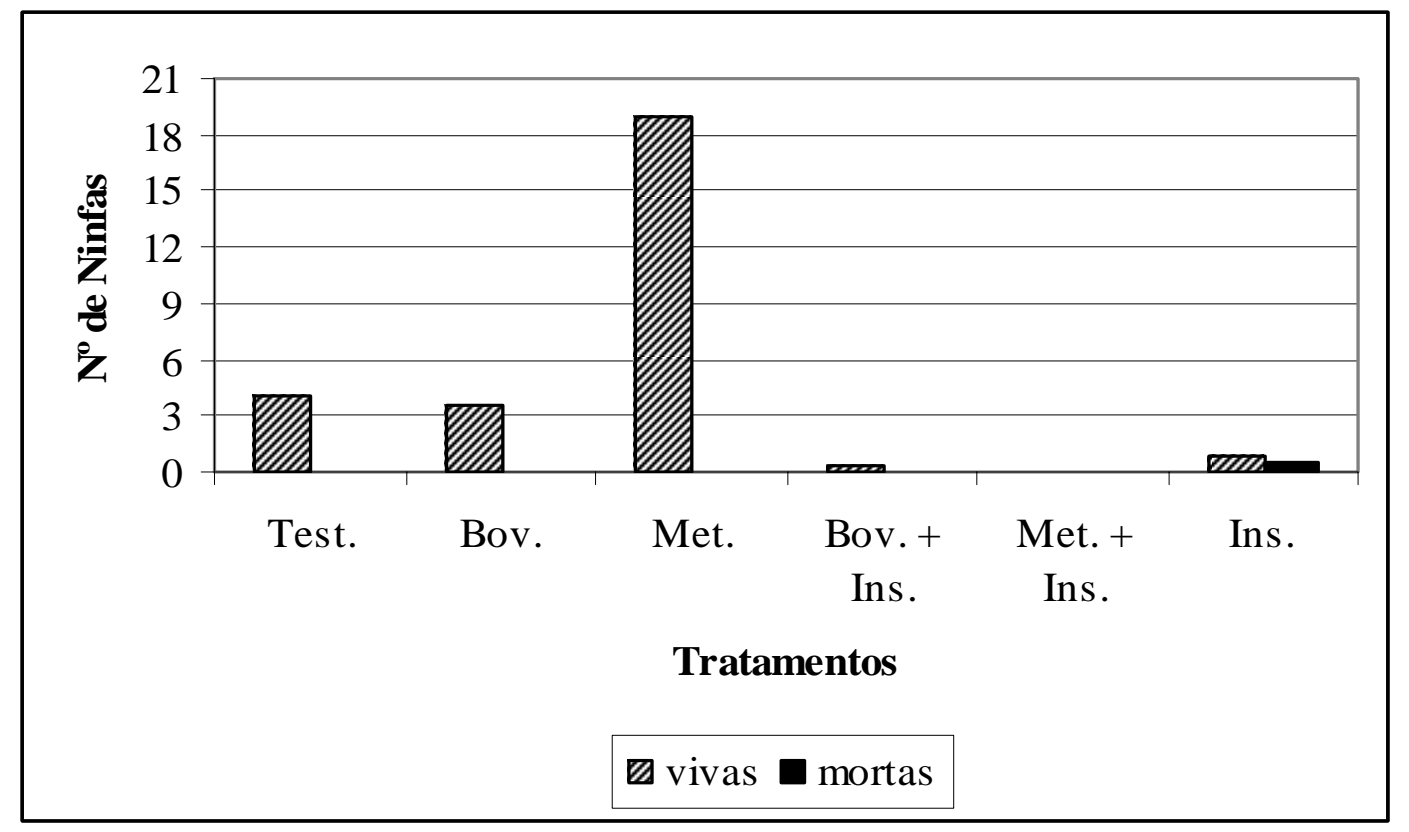

Figura 7 - Número de ninfas vivas e mortas de Bemisia tabaci, após 11 pulverizações ( $\left.26^{\circ} \mathrm{C} ; 75 \% \mathrm{UR}\right)$ 


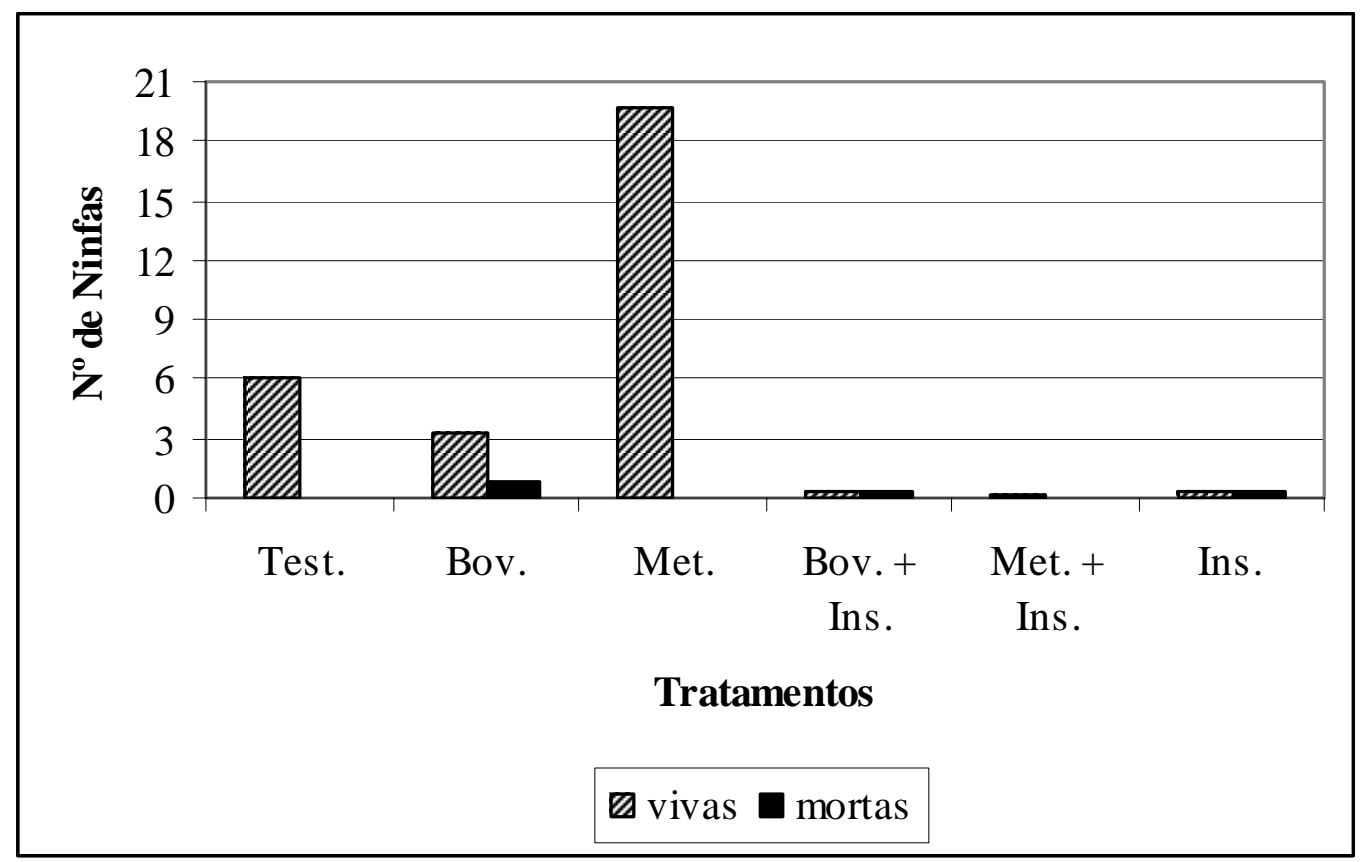

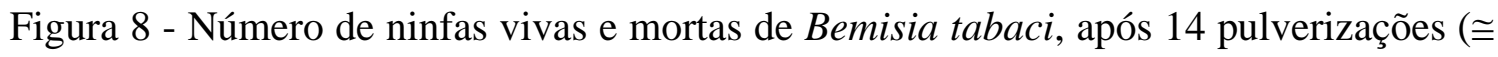
$\left.26,1^{\circ} \mathrm{C} ; 72,9 \% \mathrm{UR}\right)$

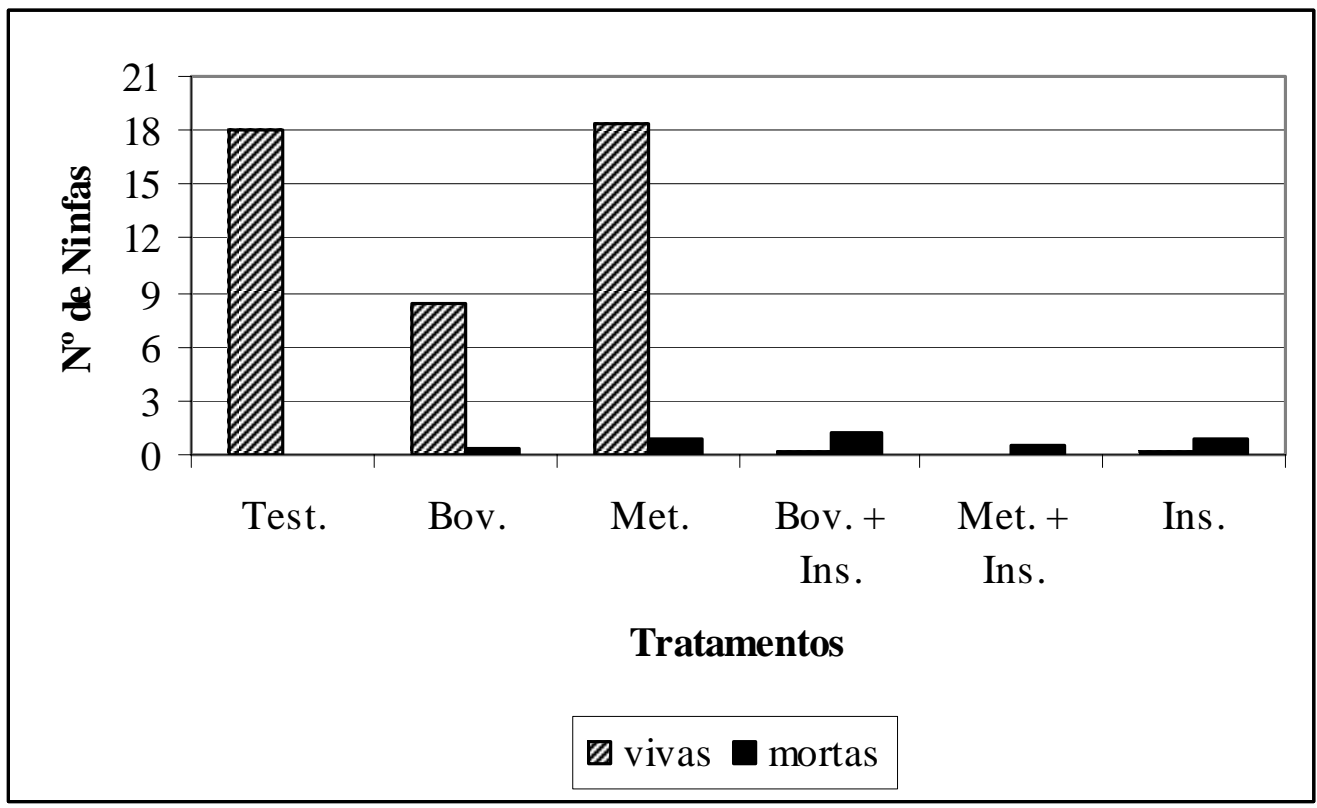

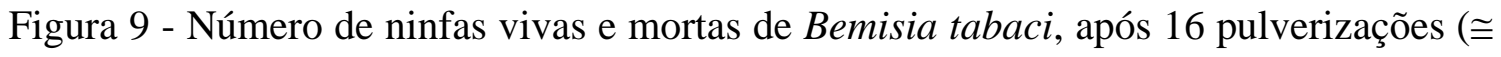
$\left.26,1^{\circ} \mathrm{C} ; 72,9 \% \mathrm{UR}\right)$ 


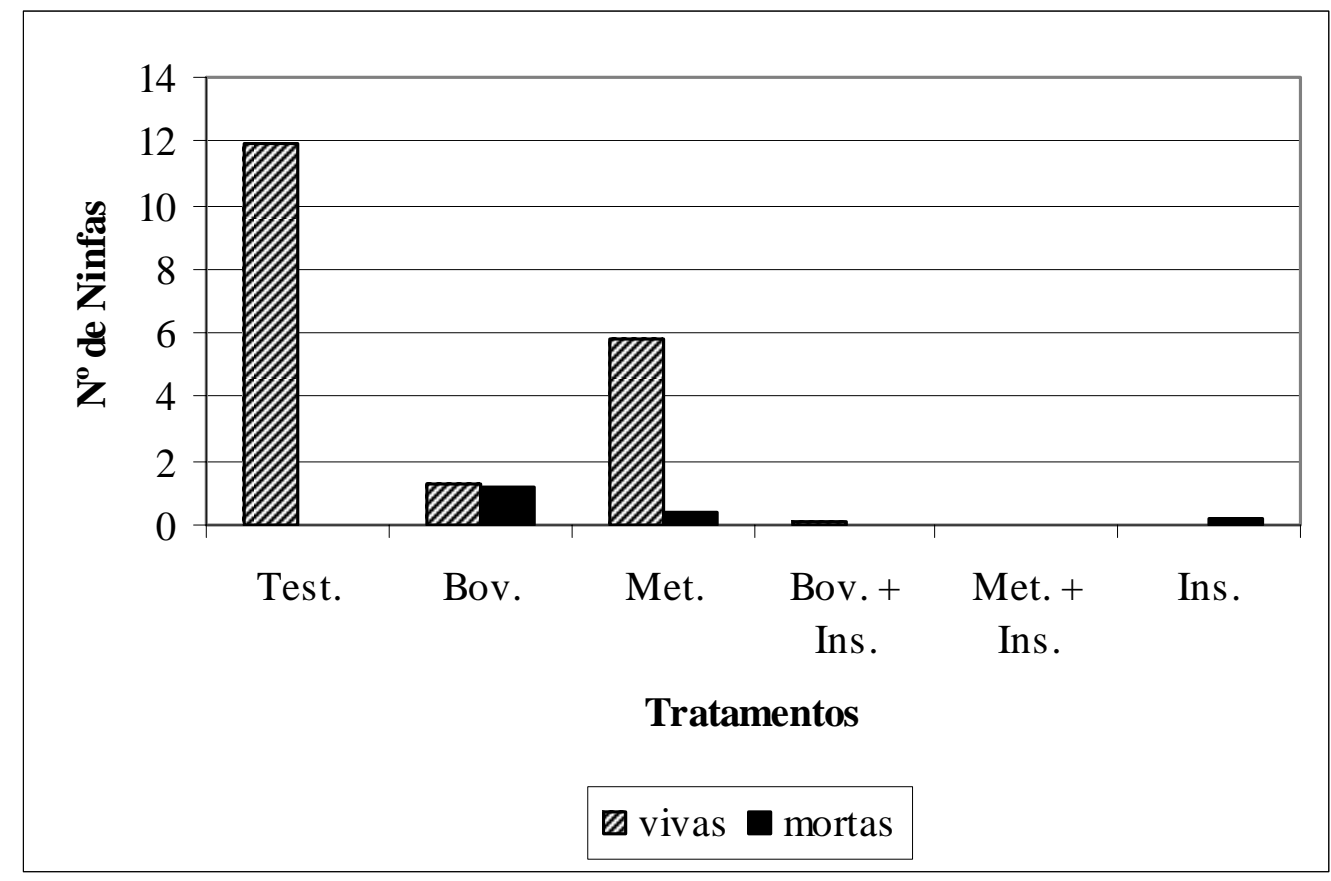

Figura 10 - Número de ninfas vivas e mortas de Bemisia tabaci, após 18 pulverizações $\left(\cong 26,1^{\circ} \mathrm{C} ; 72,9 \% \mathrm{UR}\right)$

Observou-se na testemunha o crescimento no número de ninfas até a $16^{\text {a }}$ pulverização (Figuras 7, 8 e 9), decrescendo somente na avaliação realizada após a $18^{\mathrm{a}}$ pulverização (Figura 10). Não foi observada a presença de ninfas mortas nas plantas da testemunha. Todas as ninfas apresentavam a coloração habitual amarelo-pálido, sem a presença de deformações ou qualquer alteração morfológica visível.

Nas plantas pulverizadas com Boveril ${ }^{\circledR} \mathrm{PM}$, o número de ninfas encontradas foi inferior ao da testemunha nas quatro avaliações realizadas (Figuras 7, 8, 9 e 10). No entanto, se compararmos com os tratamentos onde houve associação do inseticida (Boveril $^{\circledR}$ PM + spiromesifen; Metarril PM + spiromesifen e spiromesifen), o número de ninfas foi sempre superior no tratamento com Boveril ${ }^{\circledR}$ PM. Este fato demonstra que o Boveril $^{\circledR}$ PM exerceu um controle sobre as formas jovens de B. tabaci, porém este controle foi inferior ao exercido pelos tratamentos com inseticida. Poucas ninfas mortas foram observadas sobre as folhas avaliadas. Foram consideradas mortas ninfas que 
apresentavam coloração amarelo-escuro ou marrom-claro e que apresentavam aspecto ressecado ou deformações na sua estrutura. Somente na última avaliação (Figura 10) a presença de ninfas mortas foi maior, sendo observado praticamente o mesmo número de ninfas vivas.

No tratamento utilizando o produto Metarril PM, o número de ninfas vivas observadas foi superior ao da testemunha, nas três primeiras avaliações realizadas (Figuras 7, 8 e 9). Este fato pode ter ocorrido devido a maior densidade de adultos presentes nas plantas deste tratamento (Figuras 4, 5 e 6). Nessas condições a formulação não foi eficiente no controle de ninfas de B. tabaci em tomate. Estes resultados diferem dos obtidos por Ramos (2001), em testes realizados em laboratório com ninfas de $3^{\circ}$ ínstar de B. tabaci sobre folhas de soja. Isolados do fungo M. anisopliae causaram 34 a $90 \%$ de mortalidade das ninfas em condições de estufa tipo B.O.D. a $25 \pm 1^{\circ} \mathrm{C}, 80 \pm 5 \%$ UR e 12 horas de fotofase. Essa diferença pode ter ocorrido em função da formulação do produto, já que no experimento desse autor foram utilizados esporos e não formulações.

Fatores abióticos podem ter interferido de maneira negativa na ação dos fungos sobre o inseto testado. Durante a realização deste experimento procurou-se manter sempre a temperatura da casa-de-vegetação alta (cerca de 26 a $27^{\circ} \mathrm{C}$ ), embora grandes variações tenham ocorrido, principalmente durante a noite. A umidade relativa é outro fator chave para a ação dos fungos sobre seus hospedeiros (Rombach \& Gillespie, 1988; Landa et al., 1994; Gindin et al., 2000). No entanto, o valor médio da umidade relativa durante o experimento foi de 74\%, considerado favorável ao desenvolvimento desses fungos. A elevação da umidade além de favorecer o aparecimento de algumas doenças de plantas, poderia interferir na densidade populacional de B. tabaci, pois este inseto desenvolve-se, preferencialmente, em ambiente quentes e secos (Byrne \& Bellows, 1991).

Nas avaliações realizadas nos tratamentos com o inseticida (Boveril ${ }^{\circledR} \mathrm{PM}+$ spiromesifen; Metarril PM + spiromesifen e spiromesifen), o número de ninfas vivas e mortas, foram semelhantes nos três tratamentos. Um número muito reduzido de ninfas foi encontrado sobre as folhas avaliadas. Isto pode ter ocorrido, pois segundo Wiesbrook 
(2003) e Liu (2004) este inseticida atua sobre a biosíntese de lipídeo do inseto, afetando principalmente a fase jovem, ou seja, o crescimento e mudança de ínstar.

Um efeito sinérgico era esperado na associação dos produtos a base de fungos entomopatogênicos (Boveril ${ }^{\circledR}$ PM e Metarril PM) com o produto químico. No entanto, a utilização de apenas $50 \%$ da dose comercialmente recomendada do inseticida Oberon 240 SC (spiromesifen) mostrou ser eficiente no controle de ninfas de B. tabaci biótipo B em tomateiro, em condições de semi-campo. Este fato pôde ser observado, pois no tratamento onde se utilizou uma mistura de Metarril PM com o spiromesifen, o controle de ninfas de B. tabaci foi efetivo, contudo o mesmo efeito não ocorreu no tratamento com o Metarril PM somente. 


\section{CONCLUSÕES}

- A expressão matemática proposta é adequada para a classificação toxicológica das formulações de agrotóxicos sobre fungos entomopatogênicos.

- São compatíveis com Beauveria bassiana (ESALQ 447) oito formulações: Actara 250 WG, Bulldock 125 SC, Calypso, Confidor 700 GRDA, Malathion 1000 CE, Oberon 240 SC, Orthene 750 BR e Tamaron BR. Com exceção do Malathion 1000 CE, os mesmos produtos são compatíveis com Metarhizium anisopliae (ESALQ E9) e podem ser utilizados em associação com estes patógenos.

- As formulações Applaud 250, Baythroid CE, Cordial 100, Kumulus DF e Sumidan 25 CE são tóxicos e, Cartap BR 500, Cercobin 700 PM, Dithane PM, Meothrin 300 e Supracid 400 CE muito tóxicos a B. bassiana. As formulações tóxicas e muito tóxicas são semelhantes para M. anisopliae, acrescentando-se somente a Malathion 1000 CE que foi tóxico e o Cordial 100 muito tóxico. Assim esses produtos podem afetar a ação destes entomopatógenos se forem utilizados de forma associada.

- As subdoses de Oberon 240 SC (spiromesifen) são eficientes para o controle de ninfas de $3^{\circ}$ ínstar de Bemisia tabaci causando mortalidade variável de 35,3 a $79,9 \%$.

- Larvas de Delphastus sp. não são afetadas pela ação dos fungos B. bassiana e M. anisopliae e sua associação com o produto Oberon 240 SC (spiromesifen). 
- A subdose do produto Oberon 240 SC (spiromesifen) e sua associação com os produtos Boveril $^{\circledR}$ PM e Metarril PM afetaram as ninfas de B. tabaci presentes em plantas de tomate mantidas em semi-campo. 


\section{REFERÊNCIAS BIBLIOGRÁFICAS}

AHMAD, M.; ARIF, M.I.; AHMAD, Z.; DENHOLM, I. Cotton whitefly (Bemisia tabaci) resistance to organophosphate and pyrethroid insecticides in Pakistan. Pest Management Science, v.58, p.203-208, 2001.

ALMEIDA, A.M.R.; FERREIRA, L.P.; YORINORI, J.T.; SILVA, J.F.V.; HENNING, A.A. Doenças da soja (Glycine max L.). In: KIMATI, H.; AMORIM, L.; BERGAMIN FILHO, A.; CAMARGO, L.E.A.; REZENDE, J.A.M. (Ed.). Manual de fitopatologia. 4.ed. São Paulo: Agronômica Ceres, 1997. v.2: Doenças das plantas cultivadas, cap.61, p.642-664.

ALVES, S.B. Fungos entomopatogênicos. In: ALVES, S.B. (Coord). Controle microbiano de insetos. São Paulo: Manole, 1986. cap.6, p.73-126.

ALVES, S.B.; MOINO JÚNIOR., A.; ALMEIDA, J.E.M. Produtos fitossanitários e entomopatógenos. In: ALVES, S.B. (Ed.). Controle microbiano de insetos. 2.ed. São Paulo: FEALQ, 1998a. cap.8, p.217-238.

ALVES, S.B.; ALMEIDA, J.E.M.; MOINO JÚNIOR., A.; ALVES, L.F.A. Técnicas de laboratório. In: ALVES, S.B. (Ed.). Controle microbiano de insetos. 2.ed. São Paulo: FEALQ, 1998b. cap.20, p.637-711. 
ALVES, S.B.; LOPES, J.R.S.; ALVES, L.F.A.; MOINO, J.R.A. Controle microbiano de artrópodos associados a doenças de plantas. In: MELO, I.S.; AZEVEDO, J.L. (Ed.). Controle biológico. Jaguariúna: EMBRAPA, CNPMA, 1998c. 264p.

ALVES, S.B.; SILVEIRA, C.A.; LOPES, R.B.; TAMAI, M.A.; RAMOS, E.Q.; SALVO, S. Eficácia de Beauveria bassiana, imidacloprid e thiacloprid no controle de Bemisia tabaci e na incidência do BGMV. Manejo Integrado de Plagas, n.61, p.31-36, 2001.

ANDERSON, T.E.; ROBERTS, D.W. Compatibility of Beauveria bassiana isolates with insecticide formulations used in Colorado potato beetle (Coleoptera: Chrysomelidae) control. Journal of Economic Entomology, v.76, p.1437-1441, 1983.

ANDREI, E. (Coord.). Compêndio de defensivos agrícolas: guia prático de produtos fitossanitários para uso agrícola. 6.ed. São Paulo, 1999. 672p.

ARENAS, L.D.O. Resistencia de Bemisia argentifolii a inseticidas: implicaciones y estrategias de manejo en Mexico. Manejo Integrado de Plagas, n.49, p.10-25, 1998.

BATISTA FILHO, A.; ALMEIDA, J.E.M.; LAMAS, C. Effect of thiamethoxam on entomopathogenic microorganisms. Neotropical Entomology, v.30, n.3, p.437-447, 2001.

BEEVI, S.P.; BALASUBRAMANIAN, M. Effect of buprofezin on adult life span, oviposition, egg hatch and progeny production of the cotton whitefly, Bemisia tabaci. Phytoparasitica, v.19, p.33-47, 1991. 
BELLOWS JÚNIOR, T.S; PERRING, T.M.; GILL, R.J.; HEADRICK, D.H. Description of a species of Bemisia (Homoptera: Aleyrodidae). Annals of the Entomological Society of America, v.87, p.195-206, 1994.

BYRNE, D.N.; BELLOWS JUNIOR, T.S. Whitefly biology. Annual Review of Entomology, v.36, p.431-457, 1991.

FARIA, M.; WRAIGHT, S.P. Biological control of Bemisia tabaci with fungi. Crop Protection, v.20, p.767-778, 2001.

FRANSEN, J.J. Fungi of aphids, thrips and whitefly in the greenhouse environment. In: INTERNACIONAL COLLOQUIUM ON INVERTABRATE PATHOLOGY AND MICROBIAL CONTROL, 5., Adelaide, 1990. Proceedings. Adelaide: Society for Invertabrate Pathology, 1990. p.376-380.

GARDNER, W.A.; STOREY, G.K. Sensitivity of Beauveria bassiana to selected herbicides. Journal of Economic Entomology, v.78, p.1275-1279, 1985.

GERLING, D.; ALOMAR, O.; ARNO, J. Biological control of Bemisia tabaci using predators and parasitoids. Crop Protection, v.20, p.779-799, 2001.

GINDIN, G.; GESCHTOVT, N.U.; RACCAH, B.; BARASH, I. Pathogenicity of Verticillium lecanii to different developmental stages of the silverleaf whitefly, Bemisia argentifolii. Phytoparasitica, v.28, n.3, p.1-11, 2000.

HALL, I.M.; DUNN, P.H. The effect of certain insecticides and fungicides on fungi pathogenic to the spotted alfalfa aphid. Journal of Economic Entomology, v.52, p.28-29, 1959. 
HERBÁRIO: pragas que afetam a produção do tomate. <http://www.herbario.com.br/atual/1029tomt.htmT>. (06 maio 2004).

HILJE, L. Un modelo de colaboración agricola internacional para el manejo de moscas blancas y geminivirus en America Latina y el Caribe: a model of internacional agricultural collaboration for whitefly and geminivirus managent in Latin America and Caribeen. Manejo Integrado de Plagas, n.49, p.1-9, 1998.

HUNTER, W.B.; PATTE, C.P.; SINISTERRA, X.H.; ACHOR, D.S.; FUNK, C.J.; POLSTON, J.E. Discovering new insect viruses: Whitefly Iridovirus (Homoptera: Aleyrodidae: Bemisia tabaci). Journal of Invertabrate Pathology, v.78, p.220225, 2001.

JAMES, R.R.; BUCKNER, J.S.; FREEMAN, T.P. Cuticular lipids and silverleaf whitefly stage affect conidial germination of Beauveria bassiana e Paecilomyces fumosoroseus. Journal of Invertabrate Pathology, v.84, p.67-74, 2003.

KLEESPIES, R.G.; ZIMMERMANN, G. Effect of additives on the prodution, viability and virulence of blastospores of Metarhizium anisopliae. Biocontrol Science and Technology, v.4, p.309-319, 1994.

LANDA, Z.; OSBORNE, L.; LOPEZ, F.; EYAL, J. A bioassay for determining pathogenicity of entomogenous fungi on whiteflies. Biological Control, v.4, p.341350, 1994.

LI, D.P.; HOLDOM, D.G. Effects of pesticides on growth and sporulation of Metarhizium anisopliae (Deuteromycotina: Hyphomycetes). Journal of Invertebrate Pathology, v.63, p.209-211, 1994. 
LIU, T.-X. Toxicity and efficacy of spiromesifen, a tetronic acid insecticide, against sweetpotato whitefly (Homoptera: Aleyrodidae) on melons and collards. Crop Protection, v. 23, p.505-513, 2004.

LIU, T.-X.; STANSLY, P.A. Lethal and sublethal effects of two insect growth regulator on adult Delphastus catalinae (Coleoptera: Coccinellidae), a predator of whiteflies (Homoptera: Aleyrodidae). Biological Control, v. 30, p.298-305, 2004.

LOUREIRO, E.S; MOINO JÚNIOR, A.; ARNOSTI, A.; SOUZA, G.C. Efeito de produtos fitossanitários químicos utilizados em alface e crisântemo sobre fungos entomopatogênicos. Neotropical Entomology, v.31, n.2, p.263-269, 2002.

LOURENÇÃO, A.L.; NAGAI, H. Surtos populacionais de Bemisia tabaci no Estado de São Paulo. Bragantia, v.53, p.53-59, 1994.

LOURENÇÃO, A.L.; MIRANDA, M.A.C.; ALVES, S.B. Ocorrência epizoótica de Verticillium lecanii em Bemisia tabaci biótipo B no Estado do Maranhão. Neotropical Entomology, v.30, n.1, p.183-185, 2001.

LOURENÇÃO, A.L.; YUKI, V.A.; ALVES, S.B. Epizootia de Aschersonia cf. goldiana em Bemisia tabaci (Homoptera: Aleyrodidae) biótipo B no Estado de São Paulo. Anais da Sociedade Entomológica do Brasil, v.28, n.2, p.343-345, 1999.

MALO, A.R. Estudio sobre la compatibilidad del hongo Beauveria bassiana (Bals.) Vuill. com formulaciones comerciales de fungicidas e inseticidas. Revista Colombiana de Entomologia, v.19, p.151-158, 1993.

MARQUINI, F.; PICANÇO, M.C.; GUEDES, R.N.C.; FERREIRA, P.S.F. Imidacloprid impact on arthropods associated with canopy fo common beans. Neotropical Entomology, v.32, n.2, p.335-342, 2003. 
MEDEIROS, M.B. Ação de biofertilizantes líquidos sobre a bioecologia do ácaro Brevipalpus phoenicis. Piracicaba, 2002. 110p. Tese (Doutorado) - Escola Superior de Agricultura "Luiz de Queiroz", Universidade de São Paulo.

MEEKES, E.T.M.; FRANSEN, J.J.; VAN LENTEREN, J.C. Pathogenicity of Aschersonia spp. against whiteflies Bemisia argentifolii and Trialeurodes vaporariorum. Journal of Invertebrate Pathology, v.81, p.1-11, 2002.

MOINO JÚNIOR, A.; ALVES, S.B. Efeito de imidacloprid e fipronil sobre Beauveria bassiana (Bals.) Vuill. e Metarhizium anisopliae (Metsch.) Sorok. e no comportamento de limpeza de Heterotermes tennuis (Hagen). Anais da Sociedade Entomológica do Brasil, v.27, p.611-620, 1998.

NARANJO, S.E. Conservation and evaluation of natural enemies in IPM systems for Bemisia tabaci. Crop Protection, v.20, p.835-852, 2001.

NEVES, P.M.O.J.; HIROSE, E.; TCHUJO, P.T.; MOINO JR., A. Compatibility of entomopathogenic fungi with neonicotinoid insecticides. Neotropical Entomology, v.30, n.2, p.263-268, 2001.

OLIVEIRA, C.N.; NEVES, P.M.O.J.; KAWAZOE, L.S. Compatibility between the entomopathogenic fungus Beauveria bassiana and insecticides used in coffee plantations. Scientia Agricola, v.60, n.4, p.663-667, 2003.

OLIVEIRA, M.R.V. O emprego de casas de vegetação no Brasil: vantagens e desvantagens. Pesquisa Agropecuária Brasileira, v.30, n.8, p.1049-1060, 1995. 
OLIVEIRA, M.R.V.; HENNEBERRY, T.J.; ANDERSON, P. History, current status, and collaborative research projects for Bemisia tabaci. Crop Protection, v.20, p.709-723, 2001.

OLIVEIRA, M.R.V.; AMANCIO, E.; LAUMANN, R.A.; GOMES, L.O. Natural enemies of Bemisia tabaci (Gennadius) B biotype and Trialeurodes vaporariorum (Westwood) (Hemiptera: Aleyrodidae) in Brasília, Brazil. Neotropical Entomology, v.32, n.1, p.151-154, 2003.

OMOTO, C. Modo de ação de inseticidas e resistência de insetos a inseticidas. In: GUEDES, J.C.; COSTA, I.D.; CASTIGLIONE, E. (Org.). Bases e técnicas do manejo de insetos. Santa Maria: Pallotti, 2000. p.31-49.

PACCOLA-MEIRELES, L.D.; AZEVEDO, J.L. Variabilidade natural do fungo entomopatogênico Beauveria bassiana. Arquivos do Instituto Biológico, v.33, n.3, p.657-672, 1990.

PACHAMUTHU, P.; KAMBLE, S.T.; YUEN, G.Y. Virulence of Metarhizium anisopliae (Deuteromycotina: Hyphomycetes) strain ESC-1 to the german cockroach (Dictyoptera: Blattellidae) and its compatibility with insecticides. Journal of Economic Entomology, v.92, n.2, p.340-346, 1999.

PALUMBO, J.C.; HOROWITZ, A.R.; PRABHAKER, N. Insecticidal control and resistance management for Bemisia tabaci. Crop Protection, v.20, p.739-765, 2001.

PEREIRA, R.M.; ALVES, S.B.; SOSA-GÓMEZ, D.R; MACEDO, N. Utilização de entomopatógenos no manejo integrado de pragas. In: ALVES, S.B. (Ed.). Controle microbiano de insetos. 2.ed. São Paulo: FEALQ, 1998. cap.38, p.1097-1118. 
RAMOS, E.Q. Seleção de isolados de fungos entomopatogênicos para o controle de Bemisia tabaci biótipo B. Piracicaba, 2001. 57p. Dissertação (Mestrado) - Escola Superior de Agricultura "Luiz de Queiroz", Universidade de São Paulo.

RAMOS, E.Q.; ALVES, S.B.; TANZINI, M.R.; LOPES, R.B. Susceptibilidad de Bemisia tabaci a Beauveria bassiana en condiciones de laboratorio. Manejo Integrado de Plagas, n.56, p.65-69, 2000.

ROMBACH, M.C.; GILLESPIE, A.T. Entomogenous Hyphomycetes for insect and mite control on greenhouse crops. Biocontrol News and Information, v.9, n.1, p.7-18, 1988.

SANCHEZ-PEÑA, S.R. Infectivity of Zoophthora radicans (Zygomycetes: Entomophthorales) towards Trialeurodes vaporariorum (Homoptera: Aleyrodidae) nymphs. Florida Entomologist, v.83, n.1, p.101-105, 2000.

SCARPELLINI, J.R.; RAMIRO, Z.A.; LARA, R.I.R.; SANTOS, J.C.C. Controle químico da mosca-branca Bemisia tabaci (Gennadius, 1889) biótipo B (Hemiptera: Aleyrodidae) na cultura do feijoeiro. Arquivos do Instituto Biológico, v.69, n.3, p.23-27, 2002.

SCHUSTER, D.J.; THOMPSON, S.; GILREATH, P.R. What's up with all these whiteflies? In: Tomato Institute Program, Florida, 2003. Anais. Florida, p.12-19.

SILVA, J.B.C.; GIORDANO, L.B.; FURUMOTO, O.; BOITEUX, L.S.; FRANÇA, F.H.; VILLAS BÔAS, G.L.; BRANCO, M.C.; MEDEIROS, M.A.; MAROUELLI, W.; SILVA, W.L.C.; LOPES, C.A.; ÁVILA, A.C.; NASCIMENTO, W.M.; PEREIRAI, W. EMBRAPA: cultivo de tomate para industrialização. $<$ http://sistemasdeproducao.cnptia.embrapa.br/FontesHTML/Tomate/TomateIndustr $\mathrm{ial} /$ importancia.htm>. (06 maio 2004). 
SIMMONS, A.M. Oviposition on vegetables by Bemisia tabaci, (Homoptera: Aleyrodidae): temporal and leaf surface factors. Enviromental Entomology, v.32, p.382-389, 1994.

SMITH, S.F.; KRISCHIK, V.A. Effects of biorational pesticides on four coccinellid species (Coleoptera: Coccinellidae) having potencial as biological control agents in interiorscapes. Journal of Economic Entomology, v.93, n.3, p.732-736, 2000.

STANSLY, P.A.; LIU, T.X.; VAVRINA, C.S. Response of Bemisia argentifolii (Homoptera: Aleyrodidae) to imidacloprid under greenhouse, field, and laboratory conditions. Journal of Economic Entomology, v.91, p.686-692, 1998.

TAMAI, M.A.; ALVES, S.B.; LOPES, R.B.; RAMOS, E.Q. Controle microbiano de pragas em cultivos protegidos. In: VI Ciclo sobre Controle Biológico de Pragas, ${ }^{\circ}$ 6, Campinas, 1999 Anais. Campinas: Centro Experimental do Instituto Biológico, 1999. p.28-34.

TAMAI, M.A.; ALVES, S.B.; LOPES, R.B.; FAION, M.; PADULLA, L.F.L. Toxicidade de produtos fitossanitários para Beauveria bassiana (Bals.) Vuill. Arquivos do Instituto Biológico, v.69, n.3, p.89-96, 2002.

TODOROVA, S.I.; CODERRE, D.; DUCHESNE, R.M.; CÔTÉ, J.C. Compatibility of Beauveria bassiana with selected fungicides and herbicides. Environmental Entomology, v.27, n.2, p.427-433, 1998.

TORRES, J.B.; SILVA-TORRES, C.S.A.; OLIVEIRA, J.V. Toxicity of pymetrozine and thiamethoxam to Aphelinus gossypii and Delphastus pusillus. Pesquisa Agropecuária Brasileira, v.38, n.4, p.459-466, 2003. 
VALLE, G.E.do; LOURENÇÃO, A.L.; NOVO, J.P.S. Controle químico de ovos e ninfas de Bemisia tabaci biótipo B (Hemiptera: Aleyrodidae). Scientia Agricola, v.59, n.2, p.291-294, 2002.

VAN LENTEREN, J.C. A greenhouse without pesticides: fact or fantasy? Crop Protection, v.19, p.375-384, 2000.

VIDAL, C.; OSBORNE, L.S.; LACEY, L.A.; FARGUES, J. Effect of host plant on the potencial of Paecilomyces fumosoroseus (Deuteromycotina: Hyphomycetes) for controlling the silverleaf whitefly, Bemisia argentifolii (Homoptera: Aleyrodidae) in greenhouses. Biological Control, v.12, p.191-199, 1998.

WIESBROOK, M. Pesticide update. Illinois Pesticide Review, v.16, n.2, p.5-7, 2003.

WRAIGHT, S.P; CARRUTHERS, R.I.; JARONSKI, S.T.; BRADLEY, C.A.; GARZA, C.J.; GALAINI-WRAIGHT, S. Evaluation of the entomopathogenic fungi Beauveria bassiana and Paecilomyces fumosoroseus for microbial control of the silverleaf whitefly, Bemisia argentifolii. Biological Control, v.17, p.203-217, 2000.

WRAIGHT, S.P; CARRUTHERS, R.I.; BRADLEY, C.A.; JARONSKI, S.T.; LACEY, L.A.; WOOD, P.; GALAINI-WRAIGHT, S. Pathogenicity of the entomopathogenic fungi Paecilomyces spp. and Beauveria bassiana against the silverleaf whitefly, Bemisia argentifolii. Journal of Invertebrate Pathology, v.71, p.217-226, 1998. 